\title{
The Effect of Organic Acids on Compositional Characteristic of Protein and Lipid Recovered During Isoelectric Solubilization/ Precipitation Processing of Silver Carp and the Effectiveness of these Organic Acids on the Reduction of Staphylococcus aureus
}

Maryam Ronaghi

West Virginia University

Follow this and additional works at: https://researchrepository.wvu.edu/etd

\section{Recommended Citation}

Ronaghi, Maryam, "The Effect of Organic Acids on Compositional Characteristic of Protein and Lipid Recovered During Isoelectric Solubilization/Precipitation Processing of Silver Carp and the Effectiveness of these Organic Acids on the Reduction of Staphylococcus aureus" (2013). Graduate Theses, Dissertations, and Problem Reports. 478.

https://researchrepository.wvu.edu/etd/478

This Thesis is protected by copyright and/or related rights. It has been brought to you by the The Research Repository @ WVU with permission from the rights-holder(s). You are free to use this Thesis in any way that is permitted by the copyright and related rights legislation that applies to your use. For other uses you must obtain permission from the rights-holder(s) directly, unless additional rights are indicated by a Creative Commons license in the record and/ or on the work itself. This Thesis has been accepted for inclusion in WVU Graduate Theses, Dissertations, and Problem Reports collection by an authorized administrator of The Research Repository @ WVU. For more information, please contact researchrepository@mail.wvu.edu. 
The Effect of Organic Acids on Compositional Characteristic of Protein and Lipid Recovered During Isoelectric Solubilization/Precipitation Processing of Silver Carp and the Effectiveness of these Organic Acids on the Reduction of Staphylococcus aureus

$$
\text { Maryam Ronaghi }
$$

A thesis submitted to the

Davis College of Agriculture, Forestry and Consumer Sciences

at West Virginia University

In Partial Fulfillment of the Requirements

for the degree of

Master of Science

in

Nutritional and Food Sciences

Kristen E. Matak, Ph. D., Chair

Jacek Jaczynski, Ph. D.

Litha Sivanandan, $\mathrm{Ph}$. D

Department of Animal and Nutritional Sciences

Morgantown, West Virginia

2013

Keywords: Staphylococcus aureus, Protein recovery, Organic acids 


\begin{abstract}
The Effect of Organic Acids on Compositional Characteristic of Protein and Lipid Recovered During Isoelectric Solubilization/Precipitation Processing of Silver Carp and the Effectiveness of these Organic Acids on the Reduction of Staphylococcus aureus

Maryam Ronaghi
\end{abstract}

\begin{abstract}
An effective method to recover protein, called ISP processing, uses extreme $\mathrm{pH}$ shifts to solubilize protein and then recover it by precipitation and centrifugation. The objective of this study was to determine the proximate composition of the recovered materials from ISP after processing with different acid concentrations and the bactericidal effectiveness of these acids in comparison with hydrochloric acid $(\mathrm{HCl})$ and acetic acid against Staphylococcus aureus during isoelectric solubilization and precipitation (ISP) processing. Headed and gutted silver carp were homogenized and brought to the protein solubilization $\mathrm{pH}(2.5,3.0,11.5$, or 12.5) using the acids (glacial L-lactic acid and formic acid (F\&L) in sterile distilled water at a 1:1 ratio, glacial acetic acid or concentrated hydrochloric acid) or sodium hydroxide. Concentrations of F\&L tested were $30 \%, 45 \%, 60 \%, 75 \%, 90 \%$ and $100 \%(\mathrm{v} / \mathrm{v})$. Mixture was centrifuged to separate and remove lipid and insoluble fractions. The solubilized protein was brought to the isoelectric point $(\mathrm{pH}$ 5.5) with the addition of $\mathrm{NaOH}$ or acids and recovered by centrifugation. There were no differences in proximate composition (moisture, total fat, crude protein, ash) of the recovered protein fractions $(\mathrm{P}>0.05)$, regardless of acid concentration, with the average protein concentration at $90.6 \%$. Bactericidal effectiveness was tested on $S$. aureus at processing $\mathrm{pH} 11.5$ and 12.5 using $30 \%$ formic and lactic combination and at processing $\mathrm{pH} 2.5,3.0,11.5$ and 12.5 using $\mathrm{HCl}$ or acetic acid. Microbial analysis was performed on all fractions (lipid, protein, insoluble and water) and survivors were enumerated on Baird Parker and TSA media. Significant differences were observed between the selective and growth media $(P<0.05)$ at processing $\mathrm{pH} 11.5$, while using F\&L, indicating cell injury. However, no significant differences were observed between the selective and growth media $(\mathrm{P}>0.05)$ while using $\mathrm{HCl}$ or acetic acid except for in the insoluble fractions. The greatest microbial reductions occurred at $\mathrm{pH} 12.5$ using F\&L and acetic acid with a mean $\log$ reduction of 2.61 and $2.49 \mathrm{CFU} / \mathrm{g}$ respectively in the protein fraction and a total log reduction of 2.47 and $2.45 \mathrm{CFU} / \mathrm{g}$ respectively. The results showed that a net-pasteurization effect did not occur (a 6-log reduction in microbial population) at any of the $\mathrm{pH}$ conditions and while ISP will significantly reduce $S$. aureus, further processing is required to achieve a net pasteurization effect.
\end{abstract}




\section{ACKNOWLEDGEMENTS}

This project was funded by the HATCH Program Project \# (WVA 00622).

I would like to thank my advisor, Dr. Kristen E. Matak for her guidance, encouraging words, and believing in me. I could not have done this without her support and countless hours spent on this project away from her family.

Thank you to my committee members, Dr. Jacek Jacszynski and Dr. Litha Sivanandan for providing me with their support and wisdom. I would like to thank the faculty and staff in the Animal and Nutritional Sciences Department at West Virginia University for giving me this opportunity, for their assistance, and for their continuous support.

A special thank you Sarah Beamer and Ilgin Paker for their guidance and support in completing this project. I appreciate the countless hours you spent assisting me in the laboratory. Thank you Dr. Kenney for your advice and support through this project.

Finally, my deep appreciation to my family for encouraging me to continue my education. This project would not have been possible without your support and guidance. 


\section{TABLE OF CONTENTS}

ABSTRACT

ii

ACKNOWLEDGEMENTS

iii

LIST OF TABLES

vi

LIST OF FIRGURES

vii

CHAPTER I 1

INTRODUCTION

1

REFERENCES

CHAPTER II 6

REVIEW OF LITERATURE

Effect of $\mathrm{pH}$ on protein recovery yield

Effect of ISP on compositional characteristics of recovered components

8

Effect of organic acids on protein and lipid recovery yield and proximate composition during

ISP

Staphylococcus aureus

11

Effect of ISP processing on bacterial reduction

14

REFERENCES

17 
$\begin{array}{ll}\text { INTRODUCTION } & 23\end{array}$

MATERIALS AND METHODS 26

RESULTS AND DISCUSSION 30

Part 1: Acid concentrations on proximate composition 30

Part 2: Bactericidal Effectiveness 32

REFERENCES 36

CHAPTER IV $\quad 42$

INTRODUCTION 44

MATERIALS AND METHODS 46

RESULTS AND DISCUSSION 48

REFERENCES $\quad 53$ 


\section{LIST OF TABLES}

\section{CHAPTER III}

Table 1. Proximate composition ${ }^{\text {a }}$ (percent, dry basis) of recovered lipids, proteins and insolubles from Silver carp after ISP processing using different formic and lactic acid concentrations in water at $\mathrm{pH} 11.5$

Table 2. Reduction of $S$. aureus by ISP processing with $30 \%$ formic and lactic acid (1:1 ratio) in silver carp. Values were determined by subtraction of the log of the recovered cells within a fraction from the log of the total initial inoculation (average: $7.1 \log \mathrm{CFU} / \mathrm{g}$ ). ). There were significant differences in recovery from BP and TSA $(\mathrm{P}<0.05)$.

\section{CHAPTER IV}

Table 1. Log reduction of $S$. aureus by ISP processing with acetic and hydrochloric acids in silver carp. Values were determined by subtraction of the log of recovered cells within a fraction from the $\log$ of the total initial inoculation (average: $7.10 \log \mathrm{CFU} / \mathrm{g}$ ).

Table 2. Log reduction of $S$. aureus exposed to several $\mathrm{pH}$ shifts in different fractions of headed and gutted silver carp. Values were determined by subtraction of the log of recovered cells within a fraction from the $\log$ of the total initial inoculation (7.10 $\log \mathrm{CFU} / \mathrm{g})$. Combined data from TSA and BP There were no significant differences in recovery between TSA and BP $(\mathrm{P}>0.05)$. 


\section{LIST OF FIGURES}

\section{CHAPTER III}

Figure 1. Recovered S. aureus at pH 11.5 on BP and TSA after ISP processing. The left pie chart indicates the percentage of recovered cells from the initial inoculum and the right pie chart indicates the percentage of recovered cells in each fraction. Total log reduction was calculated by subtracting the summation of survivors in all fraction from the initial inoculum: $\log$ (initial inoculum $)-\log$ (survivors in protein fraction + insoluble fraction + lipid fraction + water fraction). The $\log$ reduction in each fraction: $\log ($ initial inoculum) $-\log$ (survivors in specific fraction).

Figure 2. Recovered $S$. aureus at $\mathrm{pH} 12.5$ after ISP processing. The left pie chart indicates the percentage of recovered cells from the initial inoculum and the right pie chart indicates the percentage of recovered cells in each fraction. Total log reduction was calculated by subtracting the summation of survivors in all fraction from the initial inoculum: $\log$ (initial inoculum) $\log$ (survivors in protein fraction + insoluble fraction + lipid fraction + water fraction). The log reduction in each fraction: $\log ($ initial inoculum $)-\log$ (survivors in specific fraction).

41

\section{CHAPTER IV}

Figure 1. Recovered S.aureus after ISP processing of silver carp at acidic processing $\mathrm{pH}$ levels. The left pie chart indicates the percentage of recovered cells from the initial inoculum and the right pie chart indicates the percentage of recovered cells in each fraction. Total log reduction was calculated by subtracting the summation of survivors in all fraction from the initial inoculum: $\log$ (initial inoculum) $-\log$ (survivors in protein fraction + insoluble fraction + lipid fraction + water fraction). The log reduction in each fraction: $\log ($ initial inoculum $)-\log ($ survivors in specific fraction).

Figure 2. Recovered S.aureus after ISP processing of silver carp at basic processing $\mathrm{pH}$ levels. The left pie chart indicates the percentage of recovered cells from the initial inoculum and the right pie chart indicates the percentage of recovered cells in each fraction. Total log reduction was calculated by subtracting the summation of survivors in all fraction from the initial inoculum: $\log ($ initial inoculum $)-\log$ (survivors in protein fraction + insoluble fraction + lipid fraction + water fraction). The log reduction in each fraction: $\log$ (initial inoculum) $\log$ (survivors in specific fraction). 


\section{Chapter I}

\section{Introduction}

The silver carp (Hypophthalmichthys molitrix) is a freshwater fish native to north and northeast Asia. In the early 1970s, these fish were brought to North America from China in an attempt to remove algae from aquaculture ponds (Conover et al., 2007). After escaping from these aquaculture ponds, they established reproducing populations in the Mississippi, Missouri, Ohio, and Illinois rivers (Chick et al., 2001). These fish are considered to be unsuitable for human consumption in the United States. However, due to their minimum growth requirements and rapid growth rate, commercial processing has become of interest. Due to the bony nature of silver carp, typical mechanical means are at removing their bones and recovering the meat. Therefore, an alternative method should be utilized to recover valuable protein and lipids from these fish (Taskaya et al., 2009).

Isoelectric solubilization and precipitation (ISP) is a method that utilizes extreme $\mathrm{pH}$ shifts (acidic or basic) to solubilize protein and separate lipid and insoluble fractions from animal tissue by centrifugation. The solubilized protein is recovered by returning the solution to its isoelectric point to allow the protein to precipitate and separate it from water by centrifuging a second time (Taskaya et al., 2009). Since this is a non-thermal process, it is important to determine the extent at which the process will reduce bacterial load in the recovered protein. The bactericidal effectiveness of the ISP protein recovery process is limited when hydrochloric acid $(\mathrm{HCl})$ is used as the processing acid. Previous studies have demonstrated that while $\mathrm{HCl}$ is effective at significantly reducing Eshchericia coli and Listeria innocua in ISP-recovered fish protein (Otto et al., 2011 a \& b; Lansdowne et al., 2009 a \& b); however, microbial reductions did not provide a 
6-log reduction, which is the reduction amount needed to be considered a pasteurization effect (FDA, 2011).

Strong acids like $\mathrm{HCl}$ dissociate within the solution and outside the bacterial cell. Acid shock or acid stress can occur in low $\mathrm{pH}$ conditions when $\mathrm{H}+$ ions cross the cell membrane and lower intracellular $\mathrm{pH}$ (Abee and Wouters, 1999). On the other hand, organic acids enter the cell in their undissociated form and dissociate once inside the cell. The bactericidal effectiveness of an acid is dependent on the dissociation of the acid within the bacterial cell. The bacterial cell must actively remove the free protons released by the acid and a high concentration of protons will cause cell death by ATP depletion (Jay et al., 2005).

The bactericidal effectiveness of organic acids (citric and acetic acid) compared to $\mathrm{HCl}$ have been demonstrated (Otto et al., 2011b). Greater reductions were observed in L. innocua populations when using citric acid or acetic acid compared to $\mathrm{HCl}$ when protein was solubilized at acidic conditions. Also, a net pasteurization effect (6-log reduction in microbial populations) was observed in all the recovered fractions when using acetic acid as the ISP processing acid at protein solubilization pH 3.0 (Otto et al., 2011b).

Staphylococcus aureus is a facultative anaerobic Gram-positive coccal bacterium that is mostly found in the nostrils and on the skin and hair of warm-blooded animals (Doyle et al., 2001). Most contaminations of food by S.aureus can be traced back to human carriers as well as contaminated equipment that were involved in the preparation process. These bacteria have the ability to tolerate a wide range of temperatures, $\mathrm{pH}$ environments, salt concentrations, and are able to survive for extended periods in a dry state (Doyle et al., 2001). 
Food poisoning by S.aureus is a common cause of gastroenteritis which is not due to the ingestion of the live organism but rather is a result of the production of enterotoxin in the staphylococci-contaminated food (Doyle et al., 2001). Symptoms of food poisoning include nausea, violent vomiting, abdominal cramping, sweating, headache, prostration, diarrhea and sometimes a drop in body temperature. Occasional hospitalization is possible for elderly and infants, but the mortality rate is very low (Bore et al., 2007). It is possible that Staphylococci exist, at least in low numbers, in all or most animal origin food products or products that have been handled directly by humans and have not been heat processed properly (Bore et al., 2007).

It has been demonstrated that the combination of antibacterial agents have a stronger antibacterial effect in contrast with each one alone. Other studies have determined that the combination of organic acids may cause a synergistic antibacterial effect. Raftari and others (2009) tested the effects of different combinations of propionic, formic and lactic acid at a 1:1 ratio and $1 \%, 1.5 \%$,and $2 \%$ concentrations when sprayed onto beef carcasses, on Staphylococcus aureus and E. coli. They found the combination of lactic and formic acid had the most lethal effect on S. aureus. Therefore, the objectives of this thesis was to

1) Determine the most effective concentration of formic and lactic acid on lipid and protein recovery yield during isoelectric solubilization and precipitation of silver carp protein.

2) Determine the bactericidal effectiveness of these acids against Staphylococcus aureus during ISP processing.

3) Compare the effectiveness of hydrochloric acid to acetic acid on the reduction of Staphylococcus aureus during the ISP protein recovery process. 


\section{References}

1. Abee, T., and J. A. wouters. 1999. Microbial stress response in minimal processing. Intl. J. Food Microbial. 50:65-91

2. Bore E, Langsrud S, Langsrud O, Rode TM, Holck A. 2007. Acid-shock responses in Staphylococcus aureus investigated by global gene expression analysis. Microbiology 153:2289-2303.

3. Conover, G., R. Simmonds, and M. Whalen, editors. 2007. Management and control plan for bighead, black, grass, and silver carps in the United States. Asian Carp Working Group, Aquatic Nuisance Species Task Force, Washington, D.C. 223 pp

4. Chick, John H., and Mark A. Pegg. "Invasive carp in the Mississippi River basin." Science 292.5525 (2001): 2250-2251.

5. Doyle MP, Beuchat LR, Montville TJ. 2001. Food Microbiology: fundamentals and frontiers 2nd ed, Washington, D.C.: ASM Press.

6. James M. Jay, Martin J. Loessner, David A. Golden. 2005. Modern Food Microbiology. New York: Springer.

7. Lansdowne, L.R., Beamer, S., Jaczynski, J., Matak, K. E. 2009a. Survival of Escherichia coli after Isoelectric Solubilization and Precipitation of Fish Protein. J Food Prot. 7:13981403.

8. Lansdowne, L.R., Beamer, S., Jaczynski, J., Matak, K. E. 2009b. Survival of Listeria innocua after Isoelectric Solubilization and Precipitation of Fish Protein. J Food Sci. 74(4):M201-205

9. Otto, R. A., Beamer, S., Jaczynski, J., Matak, K. E. 2011a. The Effect of Using Citric or Acetic Acid on Survival of Listeria monocytogenes During Fish Protein Recovery by Isoelectric Solubilization and Precipitation Process. J. Food Sci. 76(8):M579-83

10. Otto, R. A., Paker, I., Bane, L., Beamer, S., Jaczynski, J., Matak, K. E. 2011b. Survival of Listeria inoccua in Rainbow Trout Protein Recovered by Isoelectric Solubilization and Precipitation with Acetic and Citric Acids. J. Food Prot. 74(8): 1348-1352 
11. Raftari, M., Azizi, J., AS, A. F., Radu, S., Sekawi, Z., \& Fatimah, A. B. (2009). Practical and Novel Sterilization Approach for the Pathogenic Staphylococcus aureus Bacteria. American Journal of Infectious Diseases, 5(4), 294-300.

12. Taskaya, L., Chen, Y.C., Beamer, S., Tou, J. C., Jaczynski, J. 2009. Compositional Characteristics of Materials Recovered from Whole Gutted Silver Carp (Hypophthalmichthys molitrix) Using Isoelectrical Solubilization/ Precipitation. J. Agric. Food Chem. (57): 4259-4266. 


\section{Chapter II}

\section{Review of Literature}

Silver carp (Hypophthalmichthys molitrix) are a species of freshwater cyprinid fish, which are a variety of Asian carp native to north and northeast Asia. Silver carp are not cultured for marketing in the USA because of their jumping habits and poor handling qualities during production. They were first brought to North America from China in the early 1970s to remove algae from aquaculture ponds (Conover et al., 2007). They escaped from the aquaculture ponds into the Mississippi river, and as a result established reproducing populations in the Mississippi, Missouri, Ohio, and Illinois rivers (Chick et al., 2001). They are considered to be unsuitable for human consumption in the USA, but because of their rapid growth rate and minimum growth requirement, commercial processing has become of interest. Due to the bony nature of their carcass, typical mechanical methods are not efficient for removing their pin bones. Therefore, an alternative method should be utilized to recover valuable protein and lipid from carp. Isoelectric solubilization and precipitation (ISP) processing is a recovery method that separates protein and lipid from carcasses using extremely high or low $\mathrm{pH}$ conditions. The protein is solubilized at the extreme $\mathrm{pH}$ and then recovered by precipitation at an optimum isoelectric point and centrifugation (Taskaya et al., 2009b). Lipids are recovered by centrifugation. In the traditional method of performing ISP, hydrochloric acid $(\mathrm{HCl})$ is the acid of choice. However, some studies have shown organic acids to be more effective in bacterial reduction (Lansdowne et al., 2009 a \& b; Otto et al., 2011a \& b). Therefore, the effect of processing acids on protein and lipid recovery yield, as well as their bactericidal effectiveness, needs to be explored. 


\section{Effect of pH on protein recovery yield}

Muscles in fish consist mainly of myofibril and sarcoplasmic proteins. The myofibrillar proteins are salt soluble proteins since they are not soluble at physiological $\mathrm{pH}$ values unless salt is present at a relatively high concentration $(>0.3 \mathrm{M})$. However, these proteins can become soluble at low ionic strengths or very low or high pH levels (Stefansson and Hultin, 1994). During ISP, with the addition of acids and bases, IS values change, which impacts the solubility of proteins in solution. When these acids and bases dissociate in the solution, the conductivity, and therefore ionic strength increase accordingly. Chen and Jaczynski (2007a) have shown how changes in $\mathrm{pH}$ and IS affect the solubility of these muscle proteins. They found that waterinsoluble proteins have a maximum precipitation at $\mathrm{pH}$ 5-6 and they are soluble at $\mathrm{pH}$ values higher than 6 and lower than 5 . However, water soluble proteins approached $80 \%$ solubility at $\mathrm{pH}$ 5-5.5. Their data confirmed that solubility of water-soluble proteins isolated from trout decreased with increasing IS. Most proteins were recovered after solubilization with acid or base followed by precipitation. After applying nine different $\mathrm{pH}$ combinations, they found the best solubilization $\mathrm{pH}$ values, where $90 \%$ of proteins were recovered, were 2.5 or 13.0 followed by their precipitation at 5.5 (Chen and Jaczynski, 2007a). In a study by Kristinsson and others (2006) ISP processing on Atlantic croaker resulted in better protein recovery yields at acidic processing $\mathrm{pH}$ values rather than basic. This difference may be explained by the solubility behavior of sarcoplasmic proteins at $\mathrm{pH}$ 5.5. According to Kristinsson and Hultin (2004), ISP processing at basic $\mathrm{pH}$ values lead to less protein denaturation and protein coaggregation at $\mathrm{pH}$ 5.5. This may lead to less overall protein recovery at basic processing $\mathrm{pH}$ values. In comparison, a study by Taskaya et al. (2009b) showed that a higher protein and lipid recovery yield (94-97\% and 88$89 \%$ ) was achieved by using basic $\mathrm{pH}$ values for protein solubilization compared to acidic $\mathrm{pH}$ 
values (89-90\% and 94-97\%). Taskaya and others (2009b) determined their protein concentration by Kjeldahl assay while Kistinsson and Hultin (2004) used the Biuret method. Therefore, the difference in recovery yields may have been due to the difference in the methods used to determine protein concentration. In addition, carp is a freshwater species unlike Atlantic croaker which is a saltwater fish. Therefore, the lower protein recovery yield in croaker may have been due to inherent salinity (i.e., increased IS). Therefore, aside from $\mathrm{pH}$ values, the source of protein may also affect protein recovery yields during ISP processing.

\section{Effect of ISP on Compositional Characteristics of Recovered Components}

Several studies have demonstrated the effect of ISP on the proximate composition (including ash, moisture, lipid and crude protein) of the recovered components (protein, lipid and insolubles). During ISP, whole animals (including exoskeleton, bone, appendages and other inedible impurities) are used as the starting material (Chen at al., 2009). These impurities typically have high mineral contents; therefore, ash content is used as an indicator of how well

they are removed from the recovered components (Chen at al., 2009). Basic treatments tend to yield lower ash content in the recovered protein and lipid fractions of whole gutted silver carp compared to acidic (Taskaya et al., 2009 a \& b). Additionally, higher $(\mathrm{P}<0.05)$ ash contents were observed in the insoluble components after using basic processing $\mathrm{pH}$ values compared to acidic. Similar ash contents were reported in the protein and insoluble fractions recovered from whole krill (Chen and Jaczynski, 2007b), rainbow trout (Chen et al., 2007) and headed and gutted silver carp (Paker et al., 2013).

It is desirable to have less fat content in the proteins due to the possibility that they will become rancid. In a study Taskaya and others (2009 a \& b), basic treatments resulted in greater 
$(\mathrm{P}<0.05)$ fat removal from the recovered protein from whole gutted silver carp compared to acidic treatments. Similar results have been reported for channel catfish (Kristinsson et al., 2005), herring (Undeland et al., 2002), Atlantic croaker (Kristinsson et al., 2006), Antarctic krill (Chen and Jaczynski, 2007b) and rainbow trout (Chen and Jaczynski, 2007a). When processing oil to obtain a soapstock, free fatty acids are more readily removed with alkaline processing than acidic treatment (Nawar et al., 1996), which may in part explain the greater removal of fat from protein during basic treatments.

During ISP, the recovered insoluble fraction may contain some fat and crude protein. Taskaya and others (2009a) observed that the proteins recovered in the insoluble fraction did not solubilize with $\mathrm{pH}$ alteration, suggesting they were most likely non-muscle nitrogenous compounds. The lipids found in the insoluble fraction were likely phospholipids that can bond with water dipoles and hydrophilic parts of proteins and as a result were not separated with centrifugation (Taskaya et al., 2009a).

\section{Effect of Organic Acids on Protein and Lipid Recovery Yield and Proximate Composition During ISP}

The protein recovery yield is essential to determine the economic feasibility of a new technology. Isoelectric solubilization/precipitation can also recover fish oil which may offer human health benefits. Therefore, determination of lipid recovery yield may be helpful in understanding the economic feasibility of this method (Taskaya et al., 2009b; Gehring et al., 2011). 
Different protein yields have been reported at different processing $\mathrm{pH}$ values while using $\mathrm{HCl}$. Protein recovery yields of ISP reported in the literature range between $42 \%$ and $90 \%$ (Chen and Jaczynski, 2007b; Chen et al., 2009; Kristinsson and Liang, 2006; Taskaya et al., 2099b). During ISP processing of rainbow trout (Chen and Jaczynski, 2007b), whole Antarctic krill (Chen et al., 2009) and Atlantic croaker (Kristinsson and Liang, 2006), higher protein recovery yields were reported at acidic processing pHs. However, Taskaya and others (2009b) reported that higher $(\mathrm{P}<0.05)$ protein recovery yields were observed at basic processing $\mathrm{pHs}$. Taskaya and others (2009b) used Kjeldahl assay to determine crude protein content while Kristinsson and Liang (2006) used the Biuret method which may have led to the differences in protein recovery yields. Additionally, different species of fish, centrifugation force used during ISP and a relative concentration of water-soluble sarcoplasmic protein may have resulted in different outcomes. Sarcoplasmic proteins are only partly recovered during ISP (Chen and Jaczynski, 2007b).

In a study by Taskaya and others (2009b), basic solubilization during ISP processing of whole gutted silver carp, resulted in higher $(\mathrm{P}<0.05)$ lipid recovery yields compared to acidic $\mathrm{pH}$ values. The fat recovery yields indicated that ISP processing while using $\mathrm{HCl}$ as the processing acid, allowed efficient recovery of carp fat and may be an added benefit for fish processors.

In a study by Paker and others (2013), organic acids were used as the processing acid during ISP processing. They studied the effects of acetic acid and a 30\% formic and lactic acid combination $(\mathrm{F} \& \mathrm{~L})$ on total protein and fat recovery yields, proximate composition and mineral composition on recovered fractions. They found the highest protein and lipid recovery yield was achieved at acidic solubilization $\mathrm{pH} 2.5$ when using acetic acid and the lowest protein and lipid recovery yield was at acidic solubilization pH values when using F\&L (Paker et al., 2013). 
As mentioned earlier, it has been demonstrated that basic processing $\mathrm{pH}$ values were most effective at removing impurities from recovered protein and lipid contents and had the lowest ash content. However, in the study by Paker and others (2013), organic acids were not as successful as $\mathrm{HCl}$ at separating protein, lipid and insoluble fractions during ISP. This may be due to the difference between $\mathrm{pKa}$ value of these acids. The amount of acids present in their dissociated form in the solution is dependent on their $\mathrm{pKa}$. The $\mathrm{pKa}$ value of an acid is the $\mathrm{pH}$ where the acid is $50 \%$ in the dissociated form and $50 \%$ in the undissociated form. In this study acetic acid, lactic and formic acid have pKa values over 3.7 which means that they will not be $100 \%$ in their dissociated form during ISP processing at acidic $\mathrm{pH}$ values. This may explain why acidic processing $\mathrm{pH}$ levels with the use of organic acids had a lower protein concentration in their protein fractions. Strong acids like $\mathrm{HCl}$ have low pKa values (-6) which is why using these acids during ISP processing will result in a higher protein concentration in the protein fractions at acidic processing $\mathrm{pH}$ values. Basic processing $\mathrm{pH}$ values while using organic acids resulted in a higher protein concentration compared to acidic $\mathrm{pH}$ values. However, the protein concentrations in the recovered proteins were not as high as those reported when $\mathrm{HCl}$ was used (Paker et al., 2013).

\section{Staphylococcus aureus}

Staphylococcus aureus is a facultative anaerobic Gram-positive coccal bacterium. S. aureus is mostly found in the nostrils and on the skin and hair of warm-blooded animals. Most contaminations of food by S.aureus can be traced back to human carriers as well as contaminated equipment that were involved in the preparation process. These bacteria have the ability to tolerate a wide range of temperatures $\left(7^{\circ}\right.$ to $48.5^{\circ} \mathrm{C}$ with an optimum of 30 to $\left.37^{\circ} \mathrm{C}\right), \mathrm{pH}(4.2$ to 
9.3, with an optimum of 7 to 7.5 ) and sodium chloride concentrations (up to $15 \% \mathrm{NaCl}$ ) and survive for extended periods in a dry state (Doyle et al., 2001).

According to the Center for Disease Control and Prevention, Staphylococcus aureus, with an estimate of 241,148 illnesses in 2011, is in the top five of pathogens that result in domestically acquired foodborne illnesses (CDC, 2013). Food poisoning by S.aureus is not due to the ingestion of the live organism but rather is a result of the production of enterotoxin in the staphylococcicontaminated food (Doyle et al., 2001). Vegetative cells are commonly found on the skin and in the nose of $25 \%$ of healthy people and they do not cause an illness for their carriers. The numbers of bacteria per square inch are higher in moist areas $\left(10^{3}-10^{6}\right)$ rather than dry $\left(10-10^{3}\right)($ Kloos et al., 1994). The production of toxin by S. aureus is favored by optimal conditions; however, Staphylococci can grow under conditions that do not favor enterotoxin production (James et al., 2005). Toxin is produced throughout the logarithmic phase of growth or during the transition between the exponential and stationary phases. This bacterium is a poor competitor in complex bacterial populations which is why the greatest risk of food poisoning is when the initial micro flora is inhibited or destroyed (Bore et al., 2007). Symptoms of food poisoning by S. aureus start after 2-8 $\mathrm{h}$ of toxin consumption and typically resolve within $24-48 \mathrm{~h}$. These symptoms include nausea, violent vomiting, abdominal cramping, sweating, headache, prostration, diarrhea and sometimes a drop in body temperature. Occasional hospitalization is possible for elderly and infants, but the mortality rate is very low (Bore et al., 2007).

A common strategy to reduce bacterial growth is by the use of acid and a reduction in $\mathrm{pH}$. However, Staphylococcus aureus has a high tolerance for acids and may use a number of mechanisms to cope with a drop in $\mathrm{pH}$ levels. Generally, bacteria use proton pumps, which pump 
protons out of the cell to keep the internal $\mathrm{pH}$ level at an acceptable level. Another coping mechanism in bacteria is to increase the alkaline compounds inside the cell to counteract the acidification of the cytoplasm. Some bacteria can also form biofilms which may affect their acid resistance. According to Rode et al. (2010), S. aureus relies on ammonia production and the removal of acid groups to increase the $\mathrm{pH}$ in the medium when exposed to organic acid stress at low $\mathrm{pH}$ at exponential growth.

It has been found that organic acids and their salts have the ability to extend the shelf-life of refrigerated meats, poultry and fish by inhibiting pathogenic and spoilage bacterial growth (Ratanatriwong et al., 2009). Common organic acids that are used as additives or are naturally occurring in foods include acetic, lactic, citric, sorbic, benzoic, propionic, methyl and propyl esters of parahydroxybenzoic acid. According to Eifert et al. (1997), acetic acid inhibits bacterial growth by neutralizing the electrochemical potential of bacterial cell membranes and lowering their intracellular $\mathrm{pH}$. Acetic acid has a stronger antimicrobial activity compared to lactic acid which in part may be due to its higher pKa. When a mixture of acid is present, it is likely that lactic acid only contributes to a reduction in $\mathrm{pH}$. However, it has been observed that lactic acid also has the ability to permeate membranes which will enhance the antimicrobial activity of other substances (Salminen et al., 2004). Strong acids (i.e. hydrochloric acid) have a lower pKa compared to weak, organic acids which means strong acids are in their dissociated form in most $\mathrm{pH}$ conditions. Undissociated acids have a greater effect on microbial growth which is why organic acids have a better effect on microbial growth (Eifert et al., 1997). 


\section{Effect of ISP Processing on Bacterial Reduction}

In the traditional method of ISP processing, $\mathrm{HCl}$ is the acid of choice. It is effective at reducing Escherichia coli and Listeria innocua, however, a net pasteurization effect (a 6-log reduction in microbial population) was not reported (Lansdowne et al., 2009 a \& b). The best reductions of L. innocua occurred when protein was solubilized at $\mathrm{pH} 2.0$ with a $3.1 \mathrm{log}$ reduction; on the other hand, the best reductions of $E$. coli occurred when protein was solubilized $\mathrm{pH} 12.5$, with a $4.4 \log$ reduction (Lansdowne et al., 2009 a \& b).

Unlike strong acids that completely dissociate in solutions, organic acids dissociate once inside the bacterial cell which creates a greater drop in the intracytoplasm $\mathrm{pH}$. Organic acids have the ability to diffuse through the bacterial cell membrane and dissociate once inside the cell. This creates a more toxic environment for bacteria and therefore, organic acids have a better effect on microbial load reduction. A study by Otto et al. (2011b) evaluated the effect of acetic acid and citric acid on the reduction of Listeria innocua during ISP processing of rainbow trout. Significant reductions in microbial population loads were observed regardless of acid type or processing $\mathrm{pH}$. The greatest reduction was observed when protein was solubilized at $\mathrm{pH} 3.0$ with acetic acid which resulted in a $5.88 \log$ reduction in the combined components. When L. innocua was treated with $\mathrm{HCl}$ at $\mathrm{pH} 3.0$, only a $0.7 \log$ reduction was observed in the combined components. Acetic acid was more effective than $\mathrm{HCl}$ in microbial load reduction compared to strong inorganic acids like $\mathrm{HCl}$.

When the effect of using citric and acetic acid as the process acid during ISP processing

on the reduction of Listeria monocytogenes was evaluated on rainbow trout there were significant microbial reductions regardless of solubilization $\mathrm{pH}$ (Otto et al., 2011a). However, the greatest 
reductions were when protein was solubilized at $\mathrm{pH} 3.0$ using acetic acid, with a mean log reduction of 3.03 in the combined components. L. monocytogenes has the ability to resist highly acidic treatments by upregulating certain proteins that alter the structures of the cell's membrane and therefore, increase the cell's ability to maintain intracellular $\mathrm{pH} . \sigma^{\mathrm{B}}$ is a sigma factor (protein subunits that enable binding of bacterial RNA polymerase to specific gene promoters) that is seen in Gram-positive bacteria (including Staphylococcus aureus) which contributes to acid tolerance exhibited by Listeria (Raengpradub et al., 2008). The genes that are regulated by this sigma factor are unique to each species. L. monocytogenes and L. innocua share 49 genes that are regulated by $\sigma^{\mathrm{B}}$. However, L.monocytogenes has over 140 genes that are believed to be affected by this sigma factor. As a pathogen, L.monocytogenes has the ability to survive in a low $\mathrm{pH}$ like the gastric fluid. Therefore, it is believed that the $\sigma^{\mathrm{B}}$ stress response has adapted to this pathogen's lifestyle and may be the reason for the difference in survival between the 2 species (Ferreira et al., 2003; Raengpradub et al., 2008). The same sigma factor, $\sigma^{\mathrm{B}}$, is also present in Staphylococcus aureus and it contributes to acid tolerance in these bacteria.

Using a combination of organic acids might have a stronger bactericidal effect during ISP. This theory was further investigated by Laury et al. (2009) where they dipped a chicken inoculated with Salmonella in a mixture of lactic and citric acid for $5 \mathrm{~s}$ which resulted in a significant reduction of 2.5 logs. When acetic, lactic, propionic and formic acid were combined $1: 1$ at $1 \%, 1.5 \%$ and $2 \%$ concentrations and sprayed onto beef carcasses, significant reductions of Staphylococcus aureus were achieved (Raftari et al., 2009). It was also shown that the most lethal combination was with 1:1 lactic and formic acids at all concentrations (Raftari et al., 2009). These findings demonstrate the bactericidal potential of using organic acids and combinations of organic acids in the ISP process. 


\section{Summary}

Staphylococcus aureus has a high tolerance for high temperatures, acidic conditions and high sodium chloride content. In most cases contamination with these bacteria is due to contaminated equipment or human carriers that handled the food. Organic acids have been shown to be more effective at reducing bacteria during ISP processing. Therefore the purpose of this study was to determine the most effective formic and lactic acid combination on lipid and protein recovery yield during ISP processing of silver carp. This formic and lactic acid combination was used to test the effectiveness of ISP processing to reduce Staphylococcus aureus in silver carp and results were compared to microbial recovery when $\mathrm{HCl}$ and acetic acid were used. 


\section{References}

1. Argudín, María Ángeles; Mendoza, María Carmen; Rodicio, María Rosario. 2010. "Food Poisoning and Staphylococcus aureus Enterotoxins." Toxins 2, no. 7: 1751-1773.

2. Bore E, Langsrud S, Langsrud O, Rode TM, Holck A. 2007. Acid-shock responses in Staphylococcus aureus investigated by global gene expression analysis. Microbiology 153:2289-2303.

3. Centers for Disease Control and Prevention, 2013. 2011 Estimates of Foodborne Illness. http://www.cdc.gov/salmonella/typhimurium/

4. Chick, John H., and Mark A. Pegg. "Invasive carp in the Mississippi River basin." Science 292.5525 (2001): 2250-2251.

5. Chen, Y.C., Jaczynski, J. 2007b. Gelation of protein recovered from Antarctic krill (Euphausia superba) by isoelectric slubilization and precipitation as affected by function additives. J Agric Food Chem 55:1814-1822.

6. Chen, Y.C., Jaczynski, J. 2007a. Protein Recovery from Rainbow Trout (Oncorhynchus mykiss) Processing Byproducts via Isoelectric Solubilization/Precipitation and Its Gelation Properties as Affected by Functional Additives. J. Agric. Food Chem 55(22): 9079-9088.

7. Chen, Y. C., Tou, J. C., Jaczynski, J. 2009. Amino Acid and Mineral Composition of Protein and Other Components and Their Recovery Yields from Whole Antarctic Krill (Euphausia superb) Using Isoelectric Solubilization/Precipitation. Journal of Food Science. 74 (2): 31 - 39.

8. Conover, G., R. Simmonds, and M. Whalen, editors. 2007. Management and control plan for bighead, black, grass, and silver carps in the United States. Asian Carp Working Group, Aquatic Nuisance Species Task Force, Washington, D.C. 223 pp.

9. Doyle MP, Beuchat LR, Montville TJ. 2001. Food Microbiology: fundamentals and frontiers $2^{\text {nd }}$ ed, Washington, D.C.: ASM Press.

10. Erlend Bore, Solveig Langsrud, Øyvind Langsrud, Tone Mari Rode, and Askild Holck. 2007. Acid-shock responses in Staphylococcus aureus investigated by global gene expression analysis. J Microbiology, 153: 2289-2303.

11. Evenson, M.L, M.W. Hinds, R.S. Bernstein, and M.S. Bergdoll. 1988. Estimation of human dose of Staphylococcal enterotoxin A from a large outbreak of Staphylococcal food poisoning involving chocolate milk. Int. J. Food Microbiol. 7:311-316. 
12. Ferreira A, Sue D, O’Byrne CP, Boor KJ. 2003. Role of Listeria monocytogenes $\sigma^{\mathrm{B}}$ in survival of lethal acidic conditions and in the acquired acid tolerance response. Appl Environ Microbiol. 69(5):2692-8.

13. James M. Jay, Martin J. Loessner, David A. Golden. 2005. Modern Food Microbiology. New York: Springer.

14. Kristinsson, H.G., Theodore, A. E., Demir, N., Ingadotir, B. A comparative study between acid- and alkali aided processing and surimi processing for the recovery of proteins from channel catfish muscle. J. Food Sci. 70: C298-C306.

15. Kristinsson H.G., Liang Y. 2006. Effect pf $\mathrm{pH}$-shift processing and surimi processing on Atlantic croaker (Micropogonias undulates) muscle proteins. J Food Sci, 71: C304-12.

16. Kloos, W.E. and T.L. Bannerman. 1994. Update on clinical significance of coagulasenegative staphylococci. Clin. Microbiol. Rev. 7:117-140.

17. Lansdowne, L.R., Beamer, S., Jaczynski, J., Matak, K. E. 2009a. Survival of Escherichia coli after Isoelectric Solubilization and Precipitation of Fish Protein. J Food Prot. 7:13981403.

18. Lansdowne, L.R., Beamer, S., Jaczynski, J., Matak, K. E. 2009b. Survival of Listeria innocua after Isoelectric Solubilization and Precipitation of Fish Protein. J Food Sci. 74(4):M201-205.

19. Laury, A. M., Alvarado, M. V., Nace, G., Alvarado, C. Z., Brooks, J. C., Echeverry, A., Brashears, M. M., 2009. Validation of a Lactic Acid and Citric Acid Based Antimicrobial Product for the Reduction of Escherichia coli O157: H7 and Salmonella on Beef Tips and Whole Chicken Carcasses. J. Food Prot. 2009; 72(10): 2208- 2211.

20. Paker, I., Beamer, S., Jaczynski, J. and K.E. Matak. 2013. Compositional Characteristics of Materials Recovered from Headed Gutted Silver Carp (Hypophthalmichthys molitrix) By Isoelectric Solubilization and Precipitation Using Organic Acids. J. Food Sci. 78:E445-451.

21. Nawar W. W. Lipids. In Food Chemistry, 3rd ed.; Fennema, O. R., Ed.; Marcel Dekker: New York, 1996; pp 226-314. 
22. Otto, R. A., Beamer, S., Jaczynski, J., Matak, K. E. 2011a. The Effect of Using Citric or Acetic Acid on Survival of Listeria monocytogenes During Fish Protein Recovery by Isoelectric Solubilization and Precipitation Process. J. Food Sci. 76(8):M579-83.

23. Otto, R. A., Paker, I., Bane, L., Beamer, S., Jaczynski, J., Matak, K. E. 2011b. Survival of Listeria inoccua in Rainbow Trout Protein Recovered by Isoelectric Solubilization and Precipitation with Acetic and Citric Acids. J. Food Prot. 74(8): 1348-1352.

24. Paker, I., Beamer, S., Jaczynski, J. and K.E. Matak. 2013. Compositional Characteristics of Materials Recovered from Headed Gutted Silver Carp (Hypophthalmichthys molitrix) By Isoelectric Solubilization and Precipitation Using Organic Acids. J. Food Sci. 78:E445-451.

25. Raengpradub S, Wiedmann M, Boor KJ. 2008. Comparative analysis of the $\sigma \mathrm{B}$-dependent stress responses in Listeria monocytogenes and Listeria innocua strains exposed to selected stress conditions. Appl Environ Microbiol 74(1):158-71.

26. Raftari, M., Azizi, J., AS, A. F., Radu, S., Sekawi, Z., \& Fatimah, A. B. (2009). Practical and Novel Sterilization Approach for the Pathogenic Staphylococcus aureus Bacteria. American Journal of Infectious Diseases, 5(4), 294-300.

27. Ratanatriwong P.,Prachaiyo P. and Wongsa-Ngasri P. 2009. Effect of organic acid and salt mixture on shelf-life extension and growth inhibition of Staphylococcus aureus and Escherichia coli O157:H7 in moo yor. As. J. Food Ag. 2(03), 351-361

28. Rode TM, Møretrø T, Langsrud S, Langsrud O, Vogt G, Holck A. 2010. Responses of Staphylococcus aureus exposed to $\mathrm{HCl}$ and organic acid stress. Can J Microbiol. (56):777(Hypophthalmichthys molitrix) Using Isoelectrical Solubilization/ Precipitation. J. Agric. Food Chem. (57): 4259-4266.

29. Salminen S., Wright A., Ouwehand A. 2004. Lactic Acid Bacteria: Microbiological and Functional Aspects $3^{\text {rd }}$ ed. New York: Marcel Decker.

30. Stefansson, G. and Hultin, H.O. 1994. On the solubility of cod muscle protein in water. J. Agric. Food Chem. 42(12), 2656-2664.

31. Taskaya, L., Chen, Y.C., Beamer, S., Tou, J. C., Jaczynski, J. 2009. Compositional Characteristics of Materials Recovered from Whole Gutted Silver Carp 
32. Undeland, I., Kelleher, S. D., \& Hultin, H. O. (2002). Recovery of functional proteins from herring (Clupea harengus) light muscle by an acid or alkaline solubilization process. Journal of agricultural and food chemistry, 50(25), 7371-7379. 


\section{Chapter III}

\section{Isoelectric Solubilization and Precipitation of Silver Carp Protein with Increasing Formic and Lactic Acid Concentrations and their Bactericidal Effectiveness on Staphylococcus aureus}

Maryam Ronaghi, Sarah Beamer, Jacek Jaczynski, Litha Sivanandan, Kristen E. Matak,

West Virginia University, Animal and Nutritional Sciences, Morgantown, WV 26506, USA.

*Corresponding Author:

Dr. Kristen Matak

Phone: 304-293-2231

Email: kristen.matak@mail.wvu.edu

S. aureus After Protein Recovery Process (...)

Choice of journal section where article should appear: Food Microbiology and Safety 


\begin{abstract}
The objective of this study was to determine the effect of different organic acid concentrations on protein concentration and the bactericidal effectiveness of these acids against Staphylococcus aureus during isoelectric solubilization and precipitation (ISP) processing. Headed and gutted silver carp were homogenized and brought to the protein solubilization $\mathrm{pH}$ (11.5) with the addition of $\mathrm{NaOH}$. Mixture was centrifuged to separate and remove lipid and insoluble fractions. The solubilized protein was brought to the isoelectric point ( $\mathrm{pH} 5.5$ ) using glacial L-lactic acid and formic acid (F\&L) in sterile distilled water at a 1:1 ratio and recovered by centrifugation. Concentrations tested were $30 \%, 45 \%, 60 \%, 75 \%, 90 \%$ and $100 \%(\mathrm{v} / \mathrm{v})$. There were no differences in the concentration of crude protein in the recovered protein fractions $(\mathrm{P}>0.05)$, regardless of acid concentration, with the average protein concentration at $90.6 \%$. Bactericidal effectiveness was tested on $S$. aureus at processing $\mathrm{pH} 11.5$ and 12.5 using $30 \%$ formic and lactic acid combination. Microbial analysis was performed on all fractions (lipid, protein, insoluble and water) and survivors were enumerated on Baird Parker and TSA media. Significant differences were observed between the selective and growth media $(P<0.05)$ at processing $\mathrm{pH} 11.5$, indicating cell injury. The greatest microbial reductions occurred at $\mathrm{pH} 12.5$ with a mean $\log$ reduction of $2.61 \mathrm{CFU} / \mathrm{g}$ in the protein fraction and a total $\log$ reduction of $2.47 \mathrm{CFU} / \mathrm{g}$. The results showed that a net-pasteurization effect did not occur (a 6-log reduction in microbial population) at any of the $\mathrm{pH}$ conditions.
\end{abstract}

KEYWORDS: Staphylococcus aureus, fish, formic acid, protein recovery, organic acid 


\section{Introduction}

The silver carp (Hypophthalmichthys molitrix) is a freshwater cyprinid fish native to north and northeast Asia. Silver carp were introduced to North America from China in the early 1970s to remove algae from aquaculture ponds (Conover et al., 2007). They escaped from the aquaculture ponds into the Mississippi River, and as a result established reproducing populations in the Mississippi, Missouri, Ohio, and Illinois rivers (Chick et al., 2001). Silver carp are not typically harvested for human consumption in the United States because standard fish processing methods are not efficient at removing pin bones from their boney carcasses; however, their rapid growth rate and minimum growth requirements make silver carp a resource of high quality protein and lipids that is not currently being utilized.

Isoelectric solubilization and precipitation (ISP) method is a recovery process that uses extremely high or low $\mathrm{pH}$ conditions to solubilize protein and separate lipid in animal tissue. The protein is then precipitated at the isoelectric point of the protein and recovered by centrifugation (Taskaya et al., 2009b). ISP process recovery yields are species specific and dependent on processing parameters such as $\mathrm{pH}$ of protein solubilization, $\mathrm{pH}$ of protein precipitation, type of processing acid/base used, etc (Chen and Jaczynski, 2007b; Chen et al., 2009; Paker et al., 2013; Taskaya et al., 2009b).

The purity of the recovered protein is an important indicator of ISP effectiveness; proximate composition is used to determine the make-up of the recovered protein fraction. The concentration of protein in the "recovered protein" fraction reported in the literature ranges from 54\% to 95\% for ISP-recovered protein (Chen and Jaczynski, 2007b; Paker et al., 2013; Taskaya et al., 2099 a \& b). Protein concentration in the recovered protein fractions were best when protein 
was solubilized in basic conditions for Atlantic croaker (Kristinsson and Liang, 2006) and silver carp (Paker et al., 2013; Taskaya et al., 2009 a \& b).

Traditionally, hydrochloric acid is used as the processing acid with the ISP protein recovery method. Paker and others (2013) studied the effectiveness of acetic acid or a 30\% formic and lactic acid combination (F\&L) as the processing acid to recover protein from silver carp. When protein was solubilized under basic conditions, protein concentrations were comparable studies where $\mathrm{HCl}$ was used as the processing acid. Although proximate analysis revealed that basic solubilization conditions were more effective at removing impurities, the recovered fractions when $\mathrm{HCl}$ was used as the processing acid were more pure (Paker et al., 2013; Taskaya et al., 2009b). The bactericidal effectiveness of the ISP protein recovery process is limited when hydrochloric acid $(\mathrm{HCl})$ is used as the processing acid to reduce of Listeria innocua in protein solubilized under acidic conditions and Escherichia coli in protein solubilized under basic solubilization conditions (Lansdowne et al. 2009 a \& b). Unlike strong acids that completely dissociate in solutions, organic acids dissociate once inside the bacterial cell which creates a greater drop in the intracytoplasmic pH (Jay et al., 2005). Organic acids have the ability to diffuse through the bacterial cell membrane and dissociate once inside the cell. This creates a more toxic environment for bacteria and therefore, organic acids have a better effect on microbial load reduction (Eifert et al., 1997). Otto et al. (2011b) evaluated the effect of acetic acid and citric acid on the reduction of Listeria innocua during ISP processing of rainbow trout and reported higher reductions in microbial population loads compared to $\mathrm{HCl}$.

Combining organic acids may create a synergistic antibacterial effect on bacteria. This may be due to an increase of protons ions or an increase in the undisocciated form of these acids in an aqueous environment when they are combined as opposed to when they are used alone 
(Malicki et al., 2004). Raftari and co-workers (2009) further investigated this effect by using different organic acids combinations at different concentrations as a spray, to treat Staphylococcus aureus on meat carcasses. They found significant reductions in microbial populations especially when formic and lactic acids were combined at a 1:1 ratio. Therefore, the objectives of this study were to determine 1) the most effective concentration of formic and lactic acid to maximize protein concentration during isoelectric solubilization and precipitation of silver carp protein, and 2) the bactericidal effectiveness of these acids against Staphylococcus aureus during ISP processing. 


\section{Materials and Methods}

\section{Part 1: Acid concentrations on proximate composition and recovery yields}

Sample preparation. Whole, gutted silver carp (Hypophthalmichthys molitrix) was purchased (Fin International LLC., New Orleans, LA), shipped overnight on ice, headed and dipped for 10 sec in a $50 \mathrm{ppm}$ bleach solution. The sanitized fish was ground into a thick paste in a food processor (BIRO, Marblehead, Ohio, model 12) which was sanitized using a 70\% alcohol solution and UV light for $15 \mathrm{~min}$. The paste was divided into freezer bags and stored at $-80^{\circ} \mathrm{C}$ (Lansdowne et al., 2009).

Isoelectric solubilization and precipitation. Approximately $255 \mathrm{~g}$ or $155 \mathrm{~g}$ (for bactericidal effectiveness study) of frozen carp was thawed at $4^{\circ} \mathrm{C}$ for $24 \mathrm{~h}$. Defrosted fish was homogenized (Omni General Lab Homogenizer-115) with distilled, deionized water $\left(4^{\circ} \mathrm{C}\right)$ at 1:6 (w/v) ratio, 10 $\mathrm{N}$ sodium hydroxide $(\mathrm{NaOH})$ was added until the $\mathrm{pH}$ was 11.5 or 12.5 (for bactericidal effectiveness study), and the mixture was homogenized for an additional $10 \mathrm{~min}$. Temperature was maintained at $4^{\circ} \mathrm{C}$ by submerging the beaker of paste in an ice bath to reduce the activity of carp endogenous proteases. The solution was transferred into centrifuge bottles and centrifuged at $10,000 \times \mathrm{G}$ for $10 \mathrm{~min}$ at $4^{0} \mathrm{C}$ to separate the lipids and the insoluble portions (scales, bones, skin, etc.) from the protein. The supernatant, which includes solubilized protein, was poured through a cheese cloth to recover the lipid portion while the insoluble portions remained at the bottom of the centrifuge bottle. The supernatant solution with solubilized protein was brought to the isoelectric point ( $\mathrm{pH} 5.5)$ using a combination of glacial L-lactic acid (85\%, EMD Chemicals, Netherlands) and formic acid (88\%, Mallinckrodt Chemicals, Netherlands) (F\&L) in sterile distilled water at a 1:1 ratio. Concentrations tested were $30 \%, 45 \%, 60 \%, 75 \%, 90 \%$ and $100 \%$ 
(v/v). After adjusting the $\mathrm{pH}$, the mixture was homogenized for an additional $10 \mathrm{~min}$ to allow for protein precipitation. The precipitated proteins were centrifuged for a second time at $10,000 \times \mathrm{G}$ for $10 \mathrm{~min}$ at $4{ }^{\circ} \mathrm{C}$. Once again, the supernatant was poured through a sterilized cheese cloth and the protein remained at the bottom of the centrifuge bottle. All components (protein, lipid, water and insoluble components) were stored at $-80^{\circ} \mathrm{C}$ until transfer to a freeze dryer (VirTis Genesis, SP Scientific, Gardiner, NY) until the probes read above $22^{\circ} \mathrm{C}$, to indicate that the samples were mostly dry. Samples were stored at $4^{\circ} \mathrm{C}$ until further analyses were conducted.

Proximate Analysis. Proximate composition (moisture, crude protein, fat and ash) was determined on initial fish paste and the ISP-recovered components (lipid, protein and insoluble components) for all $\mathrm{F} \& \mathrm{~L}$ concentrations according to the Association of Official Analytical Chemists (1995). Moisture content was measured by evenly spreading a sample on an aluminum plate and oven-drying at $105^{\circ} \mathrm{C}$ for $24 \mathrm{hr}$. Fat and crude protein content was determined by the Soxhlet extraction method and Kjeldahl assay, respectively. Ash content was determined by burning samples in a muffle furnace at $550^{\circ} \mathrm{C}$ for $24 \mathrm{~h}$.

\section{Part 2: Bactericidal effectiveness}

Staphylococcus strain and inoculum preparation. Bactericidal effectiveness was tested on $S$. aureus at ISP protein solubilization $\mathrm{pH} 11.5$ and 12.5 using $30 \%$ formic and lactic combination. S. aureus lab strain (ATCC 25923) was revived in a $250 \mathrm{ml}$ flask containing $100 \mathrm{ml}$ sterile brain heart infusion media (BHI; all media were from Difco, Becton Dickinson, Sparks, MD unless otherwise stated) and incubated at $37^{\circ} \mathrm{C}$ for 18 to $24 \mathrm{~h}$ at $50 \mathrm{rpm}$ in a rotary incubator (Barnstead lab-line, model 305, Melrose park, IL). The culture was transferred once by loop to a $250 \mathrm{ml}$ flask 
containing $100 \mathrm{ml} \mathrm{BHI}$ and again incubated at $37^{\circ} \mathrm{C}$ for $24 \mathrm{~h}$ at $50 \mathrm{rpm}$. Cultures $(24 \mathrm{~h})$ were spread onto slants of trypticase soy agar (TSA) to create working stocks. Slants were incubated at $37^{\circ} \mathrm{C}$ for 18 to $24 \mathrm{~h}$ and then maintained for up to four weeks at $4^{\circ} \mathrm{C}$.

Cultures were transferred twice by loop inocula from slants into $100 \mathrm{ml}$ sterile BHI flasks and incubated at $37^{\circ} \mathrm{C}$ for $24 \mathrm{~h}$ in a rotary incubator at $50 \mathrm{rpm}$. After second 24-hour incubation period, cultures were transferred to sterile centrifuge bottles and centrifuged at $10,000 \times \mathrm{G}$ for 10 min at $4^{\circ} \mathrm{C}$ (Otto et al., $2011 \mathrm{a} \& \mathrm{~b}$ ). Supernatant was removed and the remaining unwashed pellet was used to inoculate $155 \mathrm{~g}$ defrosted fish paste.

Inoculation of fish paste. Defrosted fish paste was transferred to an autoclaved ceramic dish and the $S$. aureus pellet was mixed into the paste with an autoclaved spatula. The inoculated fish paste was transferred to an autoclaved beaker for ISP processing. ISP processing was conducted as described above using 30\% F\&L at protein solubilization $\mathrm{pH} 11.5$ and 12.5. Recovered fractions (protein, lipid, insoluble and water) were tested immediately for microbial survival.

Microbial analysis. Microbial analysis was performed on non-inoculated fish paste (background), inoculated fish (initial), and each fraction (lipid, protein, insoluble and water) recovered by ISP using $30 \% \mathrm{~F} \& \mathrm{~L}$ as the processing acid. For each component, a $1 \mathrm{~g}$ sample was placed in a sterile stomacher bag, mixed with $9 \mathrm{ml}$ sterile peptone buffer and hand pummeled for $2 \mathrm{~min}$. Each constituent was tenfold serially diluted and $0.1 \mathrm{ml}$ was spread plated onto TSA (nonselective) and Baird Parker (BP) medium (selective) plates and incubated at $37^{\circ} \mathrm{C}$ for $24 \mathrm{~h}$. The detection limit for non-inoculated fish paste was $<10^{3} \mathrm{CFU} / \mathrm{g},<10^{2} \mathrm{CFU} / \mathrm{g}$ for lipid, protein and insoluble fractions, and $<10 \mathrm{CFU} / \mathrm{g}$ for the process water (Otto et al., $2011 \mathrm{a} \& \mathrm{~b}$ ). Total log 
reduction was calculated by subtracting the summation of survivors in all fractions from the initial inoculum: $\log$ (initial inoculum) $-\log ($ survivors in protein fraction + insoluble fraction + lipid fraction + water fraction). The log reduction in each fraction: $\log$ (initial inoculum) $-\log$ (survivors in specific fraction) (Otto et al., 2011 a \& b; Lansdowne et al., 2009a \& b).

Statistical Analysis. The study was replicated three times for each F\&L concentration. All proximate analyses were conducted in triplicate and reported as the mean value $( \pm \mathrm{SD})$ and expressed as $\mathrm{g} \mathrm{kg}^{-1}$. For the bactericidal effectiveness study, three replicated experiments were performed for each $\mathrm{pH}$ value. Microbial counts $(\mathrm{CFU} / \mathrm{g})$ were converted into logarithmic units and recovered cells were expressed as $\log 10 \mathrm{CFU} / \mathrm{g}$. A completely random design (CRD) was used (Steel et al., 1980) and data were analyzed by analysis of variance (ANOVA). Significance was determined at 0.05 probability level and Turkey's honestly significant differences test was used to determine differences in means. All statistical analyses of data were performed using JMP 10 (SAS Inst., Cary, N.C., USA). 


\section{Results and Discussion}

\section{Part 1: Acid concentrations on proximate composition}

\section{Proximate composition}

The proximate composition of recovered lipids, proteins and insolubles from headed and gutted silver carp after ISP processing while using different concentrations of formic and lactic acid at $\mathrm{pH} 11.5$ are shown in table 1.

No differences $(\mathrm{P}>0.05)$ were observed between the concentrations of crude protein or lipid (dry basis) in the recovered protein and lipid fractions, respectively at different acid concentrations. However, the concentration of protein was higher in the recovered proteins $(\mathrm{P}<0.05)$ in comparison to the initial fish at all acid concentrations. Protein and lipid concentrations ranged from $88-93 \%$ and $85-94 \%$ in the recovered protein and lipid fractions, respectively. Taskaya and others (2009 b) reported higher values of protein concentrations at $93 \%$ in the protein fraction and lipid concentrations at $94 \%$ in the lipid fraction when $\mathrm{HCl}$ was used as the processing acid at $\mathrm{pH}$ 11.5. This may be due to the fact that unlike strong acids, like $\mathrm{HCl}$, organic acids do not dissociate completely in aqueous solutions. Organic acids, like formic and lactic acids, have different dissociation constants depending on the $\mathrm{pH}$ of the solution (Gehring et al., 2009). The amount of the available form of dissociated acid is in direct correlation to its ability to separate various fractions (protein, lipid, and insoluble) during the process of ISP. For example, when $\mathrm{HCl}$ was used as the processing acid at protein solubilization $\mathrm{pH} 11.5$, the amount of protein and lipids recovered with the insoluble fraction were 44 and 19\%, respectively (Taskaya et al., 2009b). Compared to our findings, the amount of protein and lipids recovered with the insoluble fraction that ranged from 55-64\% and $18-36 \%$, respectively. It is possible that the proteins found in the insoluble fractions were non-muscle nitrogenous 
compounds which did not solubilize with $\mathrm{pH}$ alteration (Taskaya et al., 2009b). It is also possible that the lipids found in the insoluble fraction were phospholipids that were bound with water dipoles and the hydrophilic parts of proteins and as a result were not separated with centrifugation (Taskaya et al., 2009b). On the other hand, $\mathrm{HCl}$ dissociates completely in solution so it is possible that proteins were better separated from the other fractions. This would result in an increase in solubility of protein and separation of lipid, and therefore, increasing their concentration in their appropriate fractions. Changing the concentration of acid in solution will not affect the dissociation constant, which might explain why when the concentration of F\&L increased there was no improvement in protein recovery.

Headed and gutted silver carp contains a high amount of impurities (skin, scales, bones, and so on) that need to be removed from the recovered protein and lipid components. Ash content is used as an indicator of how well these impurities were removed at each acid concentration. The average ash content (dry basis) in the recovered protein fraction was 1.99. Taskaya and others (2009b) reported an average ash concentration of 3.8\% in the protein fraction when protein was solubilized at pH 11.5 using HCL, which is consistent with our results. These results imply that using $\mathrm{F} \& \mathrm{~L}$ as the processing acid at solubilization $\mathrm{pH} 11.5$ will remove impurities at least as effectively as when $\mathrm{HCl}$ is used as the processing acid. The concentration of ash in the lipid portion ranged from $0.31-1.76$ with the $30 \% \mathrm{~F} \& \mathrm{~L}$ solution having the greatest ash concentration and the least amount in the $100 \% \mathrm{~F} \& \mathrm{~L}$ solution $(\mathrm{P}<0.05)$, implying that the $100 \%$ acid concentration was the most effective at removing impurities from the recovered lipids.

Proximate composition of the recovered lipid fraction indicated that the lipid fraction recovered was very pure. The concentration of lipid in the recovered lipid fraction ranged from 89.45 - 91.95\%; acid concentration did not affect lipid concentration of the recovered fraction ( $\mathrm{P}$ 
$>0.05$ ) since lipids were recovered before acids were added. However, Paker and others (2013) reported much lower lipid concentrations, at $60 \%$. These differences were likely due to the high moisture content of the recovered lipid fraction. On the other hand, Taskaya and others (2009 a\&b) reported lipid concentration at $94 \%$ which were consistent with the values reported in the present study.

\section{Part 2: Bactericidal Effectiveness}

\section{Staphylococcus aureus}

The average background flora of the inoculated fish was $3.4 \times 10^{3} \mathrm{CFU} / \mathrm{g}$ on TSA. There was no growth of Staphylococcus detected $\left(<10^{2} \mathrm{CFU} / \mathrm{g}\right)$ on Baird Parker. Significant differences $(\mathrm{P}<0.05)$ were observed in recovery of cells on selective media (BP) in comparison with growth media (TSA) in the recovered protein, lipid and insoluble fractions at $\mathrm{pH} 11.5$, suggesting that $S$. aureus cells were significantly injured when exposed to these conditions. The greatest microbial reductions occurred at $\mathrm{pH} 12.5$ with a mean $\log$ reduction of $2.61 \mathrm{CFU} / \mathrm{g}$ in the protein fraction $(\mathrm{P}>0.05)$ and a total $\log$ reduction of $2.47 \mathrm{CFU} / \mathrm{g}(\mathrm{P}<0.05)$. According to the U.S. Food and Drug Administration, pasteurization is defined as a 6-log reduction in microbial populations. However, a net pasteurization effect was not observed at any of the $\mathrm{pH}$ conditions. The highest number of recovered cells at $\mathrm{pH} 12.5$ was observed in the protein fraction and at $\mathrm{pH} 11.5$ the insoluble fraction contained the highest number of recovered cells. The lowest number of cells was recovered from the water fraction. Centrifugation is most likely responsible for the low number of cells in the recovered water fraction (Lansdowne et al., 2009a).

A common strategy to reduce bacterial growth is by the use of acids and a reduction in

pH. However, Staphylococcus aureus has a high tolerance for acids and may use a number of 
mechanisms to cope with a drop in $\mathrm{pH}$ levels. Generally, bacteria use proton pumps, which pump protons out of the cell to keep the internal $\mathrm{pH}$ level at an acceptable level. Another coping mechanism in bacteria is to increase the alkaline compounds inside the cell to counteract the acidification of the cytoplasm. Some bacteria can also form biofilms which may affect their acid resistance. According to Rode et al. (2010), S. aureus relies on ammonia production and the removal of acid groups to increase the $\mathrm{pH}$ in the medium when exposed to organic acid stress at low $\mathrm{pH}$ at exponential growth.

Unlike strong acids that completely dissociate in solutions, organic acids dissociate once inside the bacterial cell which creates a greater drop in the intracytoplasm $\mathrm{pH}$. Organic acids have the ability to diffuse through the bacterial cell membrane and dissociate once inside the cell. This creates a more toxic environment for bacteria and therefore, organic acids have a better effect on microbial load reduction (Jay et al., 2005). When $\mathrm{HCl}$ was used during ISP processing of rainbow trout, significant reduction were observed in Escherichia coli and Listeria innocua $(\mathrm{P}<0.05)$ in the recovered protein fraction (Lansdowne et al., 2009a \&,b). However a net pasteurization effect did not occur at any of the processing pHs. When Otto and others (2011b) used citric and acetic as the ISP processing acid for protein recovery in rainbow trout, they reported significant reductions $(\mathrm{P}<0.05)$ of $L$. innocua regardless of $\mathrm{pH}$ or acid type. A $6.41 \log \mathrm{CFU} / \mathrm{g}$ reduction was seen in the recovered protein fraction at processing $\mathrm{pH} 3.0$ with acetic acid, compared to a $1.11 \log \mathrm{CFU} / \mathrm{g}$ reduction when $\mathrm{HCl}$ was used as the processing acid (Lansdowne et al., 2009b). However, when the same organic acids and processing $\mathrm{pHs}$ were utilized during ISP processing of rainbow trout inoculated with L. monocytogenes, only a $3.53 \mathrm{CFU} / \mathrm{g}$ reduction occurred in the protein fraction (Otto et al., 2011a). 
Using a combination of organic acids might have a stronger bactericidal effect during ISP. This theory was further investigated by Laury et al. (2009) where they dipped a chicken inoculated with Salmonella in a mixture of lactic and citric acid for $5 \mathrm{sec}$ which resulted in a 2.5 $\log$ reduction of microbes. When acetic, lactic, propionic and formic acid were combined 1:1 at $1 \%, 1.5 \%$ and $2 \%$ concentrations and sprayed onto beef carcasses, significant reductions of Staphylococcus aureus were achieved (Raftari et al., 2009). It was also shown that the most lethal combination was with 1:1 lactic and formic acids at all concentrations (Raftari et al., 2009). These findings demonstrate the bactericidal potential of using organic acids and combinations of organic acids in the ISP process.

$\sigma^{\mathrm{B}}$ is a sigma factor (protein subunits that enable binding of bacterial RNA polymerase to specific gene promoters) that is seen in Gram-positive bacteria (including Staphylococcus aureus) which contributes to acid tolerance as seen in Listeria (Raengpradub et al., 2008). As a pathogen, L.monocytogenes has the ability to survive in a low $\mathrm{pH}$ like the gastric fluid. Therefore, it is believed that the $\sigma^{\mathrm{B}}$ stress response has adapted to this pathogen's lifestyle and may be the reason for the difference in survival between the 2 species (Ferreira et al., 2003; Raengpradub et al., 2008). The same sigma factor, $\sigma^{\mathrm{B}}$, is also present in Staphylococcus aureus and it contributes to acid tolerance in these bacteria. This may explain the low number of log reductions of these bacteria during ISP processing of formic and lactic acid combination. 


\section{Conclusion}

This study demonstrated that F\&L at different concentrations $(30 \%-100 \%)$ have the same effect on proximate composition (except for ash in lipid components) of recovered protein.

Therefore, $30 \%$ was the selected concentration to determine the bactericidal effectiveness of F\&L on S. aureus. There were significant differences $(\mathrm{P}<0.05)$ observed between TSA and BP media at pH 11.5 suggesting cell injury. There was a higher reduction $(\mathrm{P}<0.05)$ in cells at $\mathrm{pH} 12.5$, however, a net-pasteurization effect (6-log reduction in microbial populations) was not observed at any of the processing pHs. Staphylococcus aureus have a high tolerance for acidic conditions and have developed coping mechanisms. Therefore, future studies focusing on creating a hurdle effect with acid and other components, may be able to obtain a net-pasteurization effect after ISP processing. 


\section{References}

1. Association of Official Analytical Chemists. 1995. Official Methods of Analysis, 16th ed. Association of Official Analytical Chemists: Washington, DC.

2. Chen, Y. C., Tou, J. C., Jaczynski, J. 2009. Amino Acid and Mineral Composition of Protein and Other Components and Their Recovery Yields from Whole Antarctic Krill (Euphausia superb) Using Isoelectric Solubilization/Precipitation. Journal of Food Science. 74 (2): 31- 39.

3. Conover, G., R. Simmonds, and M. Whalen, editors. 2007. Management and control plan for bighead, black, grass, and silver carps in the United States. Asian Carp Working Group, Aquatic Nuisance Species Task Force, Washington, D.C. 223 pp

4. Doyle MP, Beuchat LR, Montville TJ. (ed.) 2001. Food Microbiology: fundamentals and frontiers. ASM Press, Washington, D.C.

5. Eifert, J. D., Hackney, C. R., Pierson, M. D., Duncan, S. E., \& Eigel, W. N. (1997). Acetic, lactic, and hydrochloric acid effects on Staphylococcus aureus 196E growth based on a predictive model. Journal of food science, 62(1), 174-178.

6. FAO, The State of World Fisheries and Aquaculture 2006. Food and Agriculture Organization of the United Nations, Rome (2007).

7. Ferreira A, Sue D, O'Byrne CP, Boor KJ. 2003. Role of Listeria monocytogenes $\sigma \mathrm{B}$ in survival of lethal acidic conditions and in the acquired acid tolerance response. Appl Environ Microbiol. 69(5):2692-8.

8. Freud, R. J.; Wilson, W. J. Design of Experiments; Academic Press: San Diego, CA, 1997; pp 464.

9. Jay M. J., Martin J. Loessner, David A. Golden. 2005. Modern Food Microbiology. New York: Springer.

10. Gehring CK, Davenport MP, Jaczynski J. 2009. Functional and nutritional quality of protein and lipid recovered from fish processing by-products and underutilized aquatic species usingisoelectric solubilization/precipitation. Curr Nutr Food Sci 5:17-39.

11. Kristinsson HG, Theodore AE, Demir N, Ingadottir B. 2005. A comparative study between acid- and alkali-aided processing and surimi processing for the recovery of proteins from channel catfish muscle. J Food Sci 70:C298-306. 
12. Lansdowne LR, Beamer S, Jaczynski J, Matak KE. 2009a. Survival of Escherichia coli after isoelectric solubilization and precipitation of fish protein. J Food Prot 7:1398-403.

13. Lansdowne, L.R., S. Beamer, J. Jaczynski, and K.E. Matak. 2009b. Survival of Listeria innocua after isoelectric solubilization and precipitation of fish protein. J. Food Sci. 74(4): M201-205.

14. Laury, A. M., Alvarado, M. V., Nace, G., Alvarado, C. Z., Brooks, J. C., Echeverry, A., Brashears, M. M., 2009. Validation of a Lactic Acid and Citric Acid Based Antimicrobial Product for the Reduction of Escherichia coli O157: H7 and Salmonella on Beef Tips and Whole Chicken Carcasses. J. Food Prot. 2009; 72(10): 2208- 2211.

15. Malicki, A., W. Zawadzki, S. Bruzewicz, S. Graczyk and A. Czerski, 2004. Effect of formic and propionic acid mixture on Escherichia coli in fish meal stored at $12^{\circ} \mathrm{C}$. Pakistan J. Nu tr., 3: 353-356.

16. American Journal of Infectious Diseases 5 (4): 301-307.

17. Otto, R. A., Beamer, S., Jaczynski, J., Matak, K. E. 2011a. The Effect of Using Citric or Acetic Acid on Survival of Listeria monocytogenes During Fish Protein Recovery by Isoelectric Solubilization and Precipitation Process. J. Food Sci. 76(8):M579-83.

18. Otto, R. A., Paker, I., Bane, L., Beamer, S., Jaczynski, J., Matak, K. E. 2011b. Survival of Listeria inoccua in Rainbow Trout Protein Recovered by Isoelectric Solubilization and Precipitation with Acetic and Citric Acids. J. Food Prot. 74(8): 1348-1352.

19. Paker, I., Beamer, S., Jaczynski, J. and K.E. Matak. 2013. Compositional Characteristics of Materials Recovered from Headed Gutted Silver Carp (Hypophthalmichthys molitrix) By Isoelectric Solubilization and Precipitation Using Organic Acids. J. Food Sci. 78:E445-451.

20. Raengpradub S, Wiedmann M, Boor KJ. 2008. Comparative analysis of the $\sigma \mathrm{B}$-dependent stress responses in Listeria monocytogenes and Listeria innocua strains exposed to selected stress conditions. Appl Environ Microbiol 74(1):158-71.

21. Raftari, M., Azizi, J., AS, A. F., Radu, S., Sekawi, Z., \& Fatimah, A. B. (2009). Practical and Novel Sterilization Approach for the Pathogenic Staphylococcus aureus Bacteria. American Journal of Infectious Diseases, 5(4), 294-300.

22. Steel GRD, Torrie JH. 1980. Principles and procedures of statistics: a biometrical approach. $2^{\text {nd }}$ ed. New York: McGraw-Hill Bok. 633 p. 
23. Taskaya L, Chen YC, Beamer S, Jaczynski J. 2009a. Texture and colour properties of proteins recovered from whole gutted silver carp (Hypophthalmichthys molitrix) using isoelectric solubilization/precipitation. J Sci Food Agric 89:349-58.

24. Taskaya, L., Chen, Y.C., Beamer, S., Tou, J. C., Jaczynski, J. 2009b. Compositional Characteristics of Materials Recovered from Whole Gutted Silver Carp (Hypophthalmichthys molitrix) Using Isoelectrical Solubilization/ Precipitation. J. Agric. Food Chem. (57): 42594266. 
Table 1. Proximate composition ${ }^{\text {a }}$ (percent, dry basis) of recovered lipids, proteins and insolubles from Silver carp after ISP processing using different formic and lactic acid concentrations in water at $\mathrm{pH} 11.5$

\begin{tabular}{|c|c|c|c|}
\hline \multicolumn{4}{|c|}{ Recovered Proteins } \\
\hline $\begin{array}{l}\text { Acid } \\
\text { Concentration }\end{array}$ & Lipid & Protein & Ash \\
\hline $30 \%$ & $4.12 \pm 1.03 b$ & $89.31 \pm 1.16$ & $1.92 \pm 0.02 \mathrm{ab}$ \\
\hline $45 \%$ & $2.82 \pm 0.62 \mathrm{~b}$ & $89.90 \pm 1.06$ & $2.40 \pm 0.26 \mathrm{a}$ \\
\hline $60 \%$ & $3.75 \pm 1.08 \mathrm{~b}$ & $91.20 \pm 2.00$ & $1.67 \pm 0.04 \mathrm{~b}$ \\
\hline $75 \%$ & $3.92 \pm 1.16 \mathrm{~b}$ & $89.81 \pm 1.34$ & $1.98 \pm 0.11 \mathrm{ab}$ \\
\hline $90 \%$ & $2.78 \pm 0.53 \mathrm{~b}$ & $90.72 \pm 2.45$ & $1.92 \pm 0.01 \mathrm{ab}$ \\
\hline $100 \%$ & $7.11 \pm 2.27 \mathrm{a}$ & $89.64 \pm 1.94$ & $2.00 \pm 0.22 \mathrm{ab}$ \\
\hline \multicolumn{4}{|c|}{ Recovered Lipids } \\
\hline $\begin{array}{l}\text { Acid } \\
\text { Concentration }\end{array}$ & Lipid & Protein & Ash \\
\hline $30 \%$ & $89.45 \pm 2.63$ & $13.24 \pm 3.811$ & $1.76 \pm 0.86 \mathrm{a}$ \\
\hline $45 \%$ & $88.68 \pm 3.75$ & $10.66 \pm 2.95$ & $1.22 \pm 0.26 \mathrm{ab}$ \\
\hline $60 \%$ & $89.50 \pm 2.56$ & $10.35 \pm 1.07$ & $1.11 \pm 0.12 \mathrm{ab}$ \\
\hline $75 \%$ & $91.95 \pm 1.84$ & $8.90 \pm 3.35$ & $0.94 \pm 0.03 \mathrm{ab}$ \\
\hline $90 \%$ & $90.95 \pm 1.51$ & $8.38 \pm 2.35$ & $0.87 \pm 0.17 \mathrm{ab}$ \\
\hline $100 \%$ & $89.97 \pm 0.80$ & $8.42 \pm 1.56$ & $0.31 \pm 0.18 \mathrm{~b}$ \\
\hline \multicolumn{4}{|c|}{ Recovered Insolubles } \\
\hline $\begin{array}{l}\text { Acid } \\
\text { Concentration }\end{array}$ & Lipid & Protein & Ash \\
\hline $30 \%$ & $23.57 \pm 10.86$ & $59.88 \pm 7.05$ & $16.86 \pm 4.09$ \\
\hline $45 \%$ & $24.61 \pm 13.45$ & $53.27 \pm 7.78$ & $23.80 \pm 1.27$ \\
\hline $60 \%$ & $29.36 \pm 3.10$ & $54.87 \pm 6.33$ & $22.05 \pm 4.19$ \\
\hline $75 \%$ & $18.94 \pm 3.1$ & $57.92 \pm 6.23$ & $22.48 \pm 5.57$ \\
\hline $90 \%$ & $25.86 \pm 2.87$ & $62.97 \pm 3.85$ & $21.92 \pm 4.86$ \\
\hline $100 \%$ & $34.26 \pm 14.11$ & $57.60 \pm 11.78$ & $18.98 \pm 7.74$ \\
\hline
\end{tabular}

${ }^{a}$ Data are given as mean \pm standard deviation $(n=3)$. Values in a column with different letters are significantly different (Tukey's honestly significant difference test, $p<0.05$ ).

For comparison, proximate analysis of headed gutted silver carp: moisture $75.4 \%$ (wet basis), total fat $32.2 \%$ (dry basis), crude protein $60.2 \%$ (dry basis) and ash $9.2 \%$ (dry basis). 
Table 2. Reduction of S. aureus by ISP processing with $30 \%$ formic and lactic acid (1:1 ratio) in silver carp. Values were determined by subtraction of the $\log$ of the recovered cells within a fraction from the log of the total initial inoculation (average: $7.10 \log \mathrm{CFU} / \mathrm{g}$ ).. There were significant differences in recovery from BP and TSA $(\mathrm{P}<0.05)$.

\begin{tabular}{|c|c|c|c|}
\hline \multirow[b]{2}{*}{ Fraction } & \multirow[b]{2}{*}{ pH } & \multicolumn{2}{|c|}{$\begin{array}{c}\text { Log Reduction } \\
(\text { mean } \log \text { CFU } / g \pm \text { SD }, n=3)\end{array}$} \\
\hline & & BP & TSA \\
\hline \multirow[t]{2}{*}{ Insoluble } & 11.5 & $0.53 \pm 0.56^{\mathrm{a}}$ & $1.67 \pm 0.24^{a}$ \\
\hline & 12.5 & $3.88 \pm 0.45^{\mathrm{b}}$ & $3.46 \pm 0.47^{b}$ \\
\hline \multirow[t]{2}{*}{ Lipid } & 11.5 & $1.36 \pm 0.38^{a}$ & $2.32 \pm 0.10^{a}$ \\
\hline & 12.5 & $3.54 \pm 0.40^{\mathrm{b}}$ & $3.45 \pm 0.27^{b}$ \\
\hline \multirow[t]{2}{*}{ Protein } & 11.5 & $0.62 \pm 0.15^{\mathrm{a}}$ & $1.65 \pm 0.22^{\mathrm{a}}$ \\
\hline & 12.5 & $2.48 \pm 0.77^{\mathrm{b}}$ & $2.73 \pm 0.76^{\mathrm{a}}$ \\
\hline \multirow[t]{2}{*}{ Water } & 11.5 & $3.53 \pm 0.67^{\mathrm{a}}$ & $4.31 \pm 0.50^{\mathrm{a}}$ \\
\hline & 12.5 & $5.66 \pm 0.96^{\mathrm{b}}$ & $5.41 \pm 0.92^{\mathrm{a}}$ \\
\hline \multirow[t]{2}{*}{ Total } & 11.5 & $0.2 \pm 0.17^{\mathrm{a}}$ & $1.29 \pm 0.17^{\mathrm{a}}$ \\
\hline & 12.5 & $2.41 \pm 0.72^{\mathrm{b}}$ & $2.53 \pm 0.64^{b}$ \\
\hline
\end{tabular}



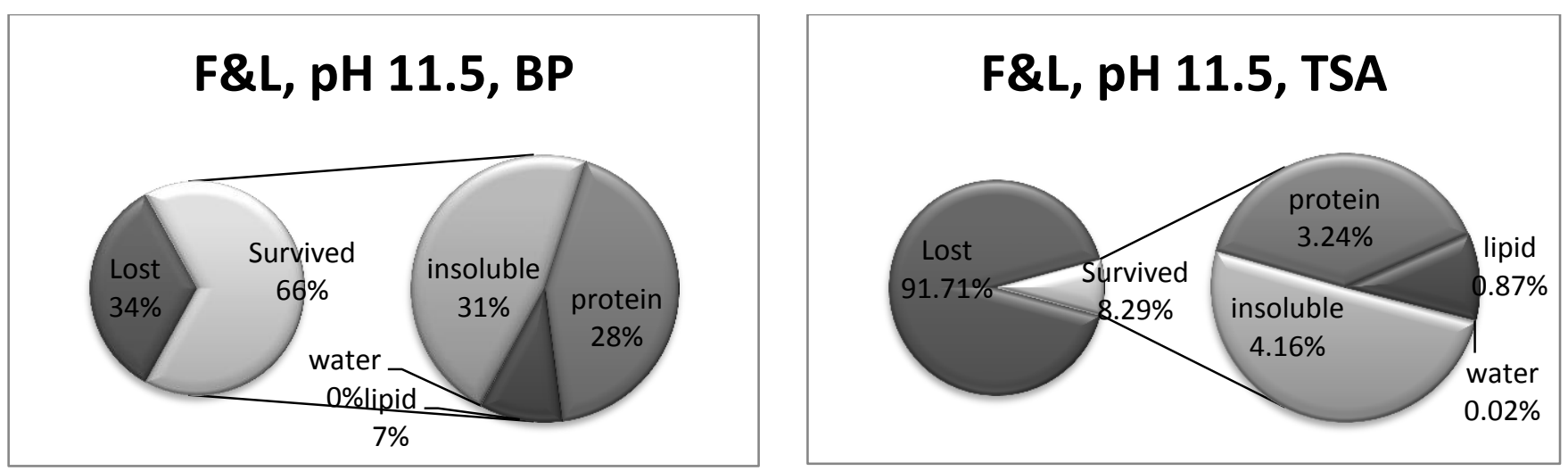

Figure 1. Recovered S. aureus at pH 11.5 on BP and TSA after ISP processing. The left pie chart indicates the percentage of recovered cells from the initial inoculum and the right pie chart indicates the percentage of recovered cells in each fraction. Total log reduction was calculated by subtracting the summation of survivors in all fraction from the initial inoculum: $\log$ (initial inoculum) $-\log$ (survivors in protein fraction + insoluble fraction + lipid fraction + water fraction). The log reduction in each fraction: log(initial inoculum) $\log$ (survivors in specific fraction).

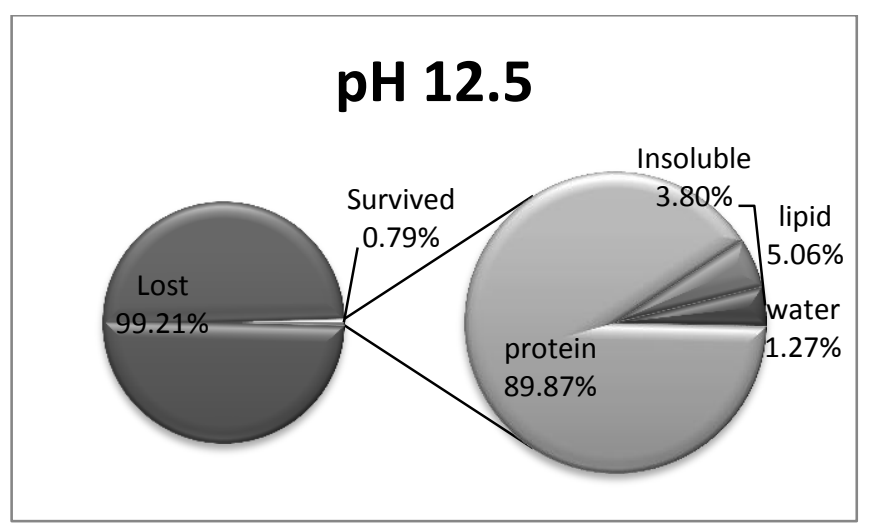

Figure2. Recovered S. aureus at pH 12.5 after ISP processing. The left pie chart indicates the percentage of recovered cells from the initial inoculum and the right pie chart indicates the percentage of recovered cells in each fraction. Total log reduction was calculated by subtracting the summation of survivors in all fraction from the initial inoculum: $\log$ (initial inoculum) - log(survivors in protein fraction + insoluble fraction + lipid fraction + water fraction). The log reduction in each fraction: $\log$ (initial inoculum) - log(survivors in specific fraction). 


\section{Chapter IV}

\section{A Comparison of the Bactericidal Effectiveness of Hydrochloric or Acetic Acid on \\ Staphylococcus aureus in Silver Carp during Isoelectric Solubilization and Precipitation Protein Recovery Process}

M. Ronaghi, S. Beamer, J. Jaczynski, L. Sivanandan, and K. E. Matak*

West Virginia University, Animal and Nutritional Sciences, Morgantown, WV 26506, USA.

*Corresponding Author:

Dr. Kristen Matak

Phone: (304) 293-1908

Email: Kristen.Matak@mail.wvu.edu

Key Words: Staphylococcus aureus; silver carp; organic acid, protein recovery

Target Journal: Journal of Food Science 


\begin{abstract}
An effective method to recover protein, called ISP processing, uses extreme $\mathrm{pH}$ shifts to solubilize protein and then recover it by precipitation and centrifugation. The bactericidal effectiveness of this process on Staphylococcus aureus has not been tested; therefore, the objective of this study was to compare acids used for the $\mathrm{pH}$ shift, hydrochloric and acetic acid, on the reduction of this bacterium during ISP processing. Headed and gutted silver carp were inoculated with $S$. aureus, homogenized and brought to the target $\mathrm{pH}(2.5,3.0,11.5$, or 12.5$)$ with the addition of glacial acetic acid, concentrated hydrochloric acid, or sodium hydroxide. Protein was solubilized at $4^{\circ} \mathrm{C}$ for $10 \mathrm{~min}$ and centrifuged to remove lipid and insoluble components (bone, skin, insoluble protein and so on). The solubilized protein was brought to the isoelectric point ( $\mathrm{pH} 5.5$ ) with the addition of $\mathrm{NaOH}, \mathrm{HCl}$ or acetic acid. Microbial analysis was performed on all the fractions (lipid, protein, insoluble and water) and survivors were enumerated on Baird Parker and Tryptic Soy Agar media. The sums of the surviving cells from each component were compared to the initial inoculum numbers. No significant differences were observed between the selective and growth media $(P>0.05)$ except for in the insoluble fractions. Significant microbial reductions were detected at all acid and $\mathrm{pH}$ combinations $(P<0.05)$. The greatest reduction was at solubilization $\mathrm{pH} 12.5$ using acetic acid, with a total reduction of $2.45 \mathrm{CFU} / \mathrm{g}$ in the combined fractions and $2.49 \mathrm{CFU} / \mathrm{g}$ in the protein fraction. These results show that while ISP will significantly reduce $S$. aureus, further processing is required to achieve a net pasteurization effect.
\end{abstract}




\section{Introduction}

Isoelectric solubilization and precipitation (ISP) processing is a non-thermal method to recover protein and lipid from by-products of fish processing. This is achieved by using extremely acidic or basic $\mathrm{pH}$ shifts to solubilize proteins so that insoluble components (skin, bones, scales, etc.) may be separated from them by centrifugation. Proteins precipitate when the solution is returned to the isoelectric point of the protein and then the protein is recovered from the process water by a second centrifugation. Since this is a non-thermal process, it is important to determine the extent at which the process will reduce bacterial load in the recovered protein. When hydrochloric acid $(\mathrm{HCl})$ is used as the processing acid, this process is effective at significantly reducing Escherichia coli and Listeria innocua in ISP-recovered fish protein (Lansdowne et al., 2009 a \& b); however, microbial reductions did not provide a 6-log reduction, which is the reduction amount needed to be considered a pasteurization effect (FDA, 2011).

The $\mathrm{pKa}$ defines the strength of an acid on a logarithmic scale and the strength of an acid is defined by the tendency of the acid to give up its proton to water and become dissociated (Gilbert 2000). Strong acids, like $\mathrm{HCl}$, have a low $\mathrm{pKa}$, which means they are mostly in their dissociated form in solutions; however, weak organic acids, like citric and acetic acid, have a higher $\mathrm{pKa}$ and are present in both dissociated and undissociated forms in solution. Strong acids dissociate within the solution and outside the bacterial cell. Acid shock or acid stress can occur in low $\mathrm{pH}$ conditions when $\mathrm{H}+$ ions cross the cell membrane and lower intracellular $\mathrm{pH}(\mathrm{Abee}$ and Wouters, 1999). On the other hand, organic acids enter the cell in their undissociated form and dissociate once inside the cell. The bactericidal effectiveness of an acid is dependent on the dissociation of the acid within the bacterial cell. The bacterial cell must actively remove the free protons released by the acid and a high concentration of protons will cause cell death by ATP 
depletion (Jay et al., 2005). Otto and others (2011b) explored the bactericidal effectiveness of using citric or acetic acids instead of $\mathrm{HCl}$ acid as the ISP processing acid. When protein was solubilized under acidic processing conditions, they reported greater reductions in L. innocua populations when citric or acetic acid was used as the processing acid when compared to $\mathrm{HCl}$. They also reported a net pasteurization effect (6-log reduction in microbial populations) in all the recovered fractions when acetic acid was used as the ISP processing acid at protein solubilization pH 3.0 (Otto et al., 2011b).

Staphylococcus aureus is a facultative anaerobic Gram-positive coccal bacterium that is mostly found in the nostrils and on the skin and hair of warm-blooded animals (Doyle et al., 2001). Most contaminations of food by S.aureus can be traced back to human carriers as well as contaminated equipment that were involved in the preparation process. This bacteria has the ability to tolerate a wide range of temperatures, $\mathrm{pH}$ environments, salt concentrations, and is able to survive for extended periods in a dry state (Doyle et al., 2001). Food poisoning by S.aureus is a common cause of gastroenteritis which is not due to the ingestion of the live organism but rather is a result of the production of enterotoxin in the staphylococci-contaminated food (Doyle et al., 2001). Symptoms of food poisoning include nausea, violent vomiting, abdominal cramping, sweating, headache, prostration, diarrhea and sometimes a drop in body temperature. Occasional hospitalization is possible for elderly and infants, but the mortality rate is very low (Bore et al., 2007). It is possible that Staphylococci exist, at least in low numbers, in all or most animal origin food products or products that have been handled directly by humans and have not been heat processed properly (Bore et al., 2007). Therefore, the objective of this study was to compare the effectiveness of hydrochloric acid to acetic acid on the reduction of Staphylococcus aureus during the ISP protein recovery process. 


\section{Material and Methods.}

Fish Preparation. Fresh silver carp (Hypophthalmichthys molitrix) was headed, gutted and sanitized by dipping in a $50 \mathrm{ppm}$ bleach solution for $10 \mathrm{sec}$ (Clorox Regular Bleach, Clorox, Oakland, CA, USA). After draining for an additional $10 \mathrm{sec}$, fish was placed in a sanitized food processor (BIRO, Marblehead, model 12, Ohio, USA) and ground into a thick paste. Equipment was sanitized by spraying with $70 \%$ ethanol and exposed to UV light $(254 \mathrm{~nm})$ for $15 \mathrm{~min}$. The paste was divided and $155 \mathrm{~g}$ was placed into freezer bags and stored at $-80{ }^{\circ} \mathrm{C}$ (Lansdowne et al., 2009)

Bacterial strain and inoculum preparation. Staphylococcus aureus lab strain (ATCC 25923) was revived in $100 \mathrm{~mL}$ sterile brain heart infusion broth in a sterile $250 \mathrm{ml}$ flask (BHI; Becton, Dickinson \& Co., Sparks, MD) and incubated at $37^{\circ} \mathrm{C}$ for 18 to $24 \mathrm{~h}$ in a rotary incubator (Barnstead lab-line, model 305, Melrose Park, IL) at $50 \mathrm{rpm}$. The initial culture was transferred by loop to a second sterile flask containing $100 \mathrm{ml}$ brain heart infusion and the same process was repeated. The initial culture was spread onto slants of trypticase soy agar (TSA; Acumedia, Lansing, MI), incubated for $18-24 \mathrm{~h}$ at $37^{\circ} \mathrm{C}$ and stored at $4^{\circ} \mathrm{C}$.

S. aureus from working stock slant was twice transferred by loop inocula into $100 \mathrm{~mL}$ sterile $\mathrm{BHI}$ flasks and incubated at $37^{\circ} \mathrm{C}$ for 18 to $24 \mathrm{~h}$ at $50 \mathrm{rpm}$ in a rotary incubator. Contents were transferred to sterile centrifuge bottles and centrifuged at $10,000 \times \mathrm{G}$ for $10 \mathrm{~min}$ at $4^{\circ} \mathrm{C}$ (Otto et al., 2011a \& b). Supernatant was removed and pellet was used to inoculate fish paste.

Inoculation of Fish Paste. Fish paste was thawed at $4^{\circ} \mathrm{C}$ for 18 to $24 \mathrm{~h}$ and emptied into an autoclaved ceramic dish. The $S$. aureus pellet was mixed into the paste using an autoclaved spatula. The inoculated paste was immediately used for ISP processing. (Otto et al., $2011 \mathrm{a} \& \mathrm{~b}$ ) 
Isoelectric solubilization/precipitation. After inoculation, $155 \mathrm{~g}$ of fish paste was placed in an autoclaved beaker and homogenized with $930 \mathrm{~mL}$ distilled (1:6 wt/vol), deionized water. Homogenizer (BIRO, Marblehead, model 12, Ohio, USA) was sanitized by spraying with $70 \%$ ethanol and placing under UV light for 15 min. Glacial acetic acid (Fischer Scientific, Fairlawn, N.L., U.S.A.), $6 \mathrm{~N}$ hydrochloric acid or $10 \mathrm{~N}$ sodium hydroxide was added to the mixture until the target $\mathrm{pH}(2.5,3.0,11.5$ or 12.5$)$ was reached. Once $\mathrm{pH}$ was adjusted, homogenization was continued for an additional $10 \mathrm{~min}$ to allow protein solubilization. The homogenized mixture was poured into autoclaved centrifuge bottles and centrifuged at $10,000 \times \mathrm{G}$ for $10 \mathrm{~min}$ at $4{ }^{\circ} \mathrm{C}$ (Otto et al., 2011 a \& b). The supernatant (solubilized protein) was poured through autoclaved cheesecloth to collect the lipid. Lipid and insoluble portions remaining on the bottom of the centrifuge tubes were retained in sterile containers for microbial analysis. The supernatant was brought to its isoelectric point ( $\mathrm{pH} 5.5$ ) by the addition of $10 \mathrm{~N} \mathrm{NaOH}$, glacial acetic acid or $6 \mathrm{~N} \mathrm{HCl}$ and homogenized for an additional $5 \mathrm{~min}$. The solution was poured into autoclaved centrifuge bottles and was centrifuged at $10,000 \times \mathrm{G}$ for $10 \mathrm{~min}$ at $4^{\circ} \mathrm{C}$ (Otto et al., $2011 \mathrm{a} \mathrm{\&} \mathrm{b).} \mathrm{Both} \mathrm{supernatant}$ and precipitated proteins were retained separately in sterile containers for microbial analysis.

Microbial Analysis. Microbial load was determined on uninoculated fish paste (background), inoculated fish paste (initial), and recovered fractions (protein, lipid, insoluble and water). An aliquot $(1 \mathrm{~g})$ was placed into separate stomacher bags with $9 \mathrm{ml}$ sterile peptone buffer and hand-pummeled for 2 min. Pummeled samples were serially diluted (10-fold) and spreadplated onto TSA (non-selective) and Baird Parker medium (BP; selective) plates and incubated at $37^{\circ} \mathrm{C}$ for $24 \mathrm{~h}$. The detection limit for non-inoculated fish paste was $<10^{3} \mathrm{CFU} / \mathrm{g}$, for lipid, protein and insoluble fractions it was $<10^{2} \mathrm{CFU} / \mathrm{g}$ and for water it was $<10 \mathrm{CFU} / \mathrm{g}$. (Otto et al., 2011 a \& b) Total $\log$ reduction was calculated by subtracting the summation of survivors in all fraction 
from the initial inoculum: $\log ($ initial inoculum $)-\log ($ survivors in protein fraction + insoluble fraction + lipid fraction + water fraction). The log reduction in each fraction: $\log ($ initial inoculum) $-\log$ (survivors in specific fraction) (Lansdowne et al., 2009 a \& b).

Statistical Analysis. This study was replicated three times for each acid type and each solubilization $\mathrm{pH}$ value. Microbial counts (CFU/g) were converted into logarithmic units and recovered cells were expressed as $\log _{10} \mathrm{CFU} / \mathrm{g}$. Data were analyzed by analysis of variance and differences in means were determined using Turkey's honestly significant differences test $(\mathrm{P}<0.05)$ (JMP 10, SAS Institute, Cary, NC).

\section{Results and Discussion}

For all trials, the mean background flora of the initial fish pasted was $3.4 \times 10^{3} \mathrm{CFU} / \mathrm{g}$ on TSA and there was no growth of Staphylococcus aureus detected $\left(<10^{2} \mathrm{CFU} / \mathrm{g}\right)$ on BP. There were no differences $(\mathrm{P}>0.05)$ in cell recovery on TSA and BP for the protein, lipids, and water fractions, implying that microbial death due to ISP processing was an "all-or-nothing event" (Table 1). This is consistent with Lansdowne and others (2009 a) and Otto and others (2011 a \& b) who found that when Listeria monocytogenes and L. innocua were exposed to the $\mathrm{pH}$-shift process, there were no differences in recovery on selective or non-selective media. In contrast, when Escherichia coli were exposed to $\mathrm{HCl}$ using the $\mathrm{pH}$-shift process, there were differences in recovery on selective and non-selective media, implying that cells were injured during the process (Lansdowne et al., 2009b). Bacterial cell injury occurs as a result of exposure to a chemical or physical process that damages but does not kill a microorganism (Hurst et al., 1997). As a result of metabolic and structural injury, microorganisms lose their characteristic growth capabilities and they are unable to form visible colonies under selective conditions, where uninjured cells are 
able to form colonies. Most injured cells suffer from structural damage, which could affect the cell wall or membrane permeability; rather than metabolic injury, where the functional components of the cell are damaged (Brashears et al., 2001). In Gram-negative bacteria, i.e. $E$. coli, damage to the outer membrane of the cell causes the release of lipopolysaccharides, lipids, phospholipids, divalent cations necessary for lipopolysaccharide stability, and periplasmic enzymes which may disrupt membrane permeability (Wesche et al., 2009). However, in the study by Lansdowne and others (2009b), the bacteria were in a rich environment provided by fish proteins and other components which may have led to the injury of cells instead of death under basic conditions. Protein rich environments contain carnitines, betaines, and peptides that protect these bacteria from adverse conditions. These components prolong the internal homeostasis of the bacteria and allow it to survive in acidic or basic conditions (Russell et al., 1995).

The greatest microbial reductions $(\mathrm{P}<0.05)$ occurred when protein was solubilized at $\mathrm{pH}$ 12.5 for both processing acids, with a total $\log$ reduction of $2.45 \mathrm{CFU} / \mathrm{g}$ and $1.86 \mathrm{CFU} / \mathrm{g}$ for acetic and $\mathrm{HCl}$ acids, respectively (Table 2). These data are consistent with the results of Ronaghi (2013) who observed that when formic and lactic acid was used as the processing acid during the ISP process, the most bactericidal protein solubilization $\mathrm{pH}$ was at $\mathrm{pH} 12.5$. The protein fraction contained the most recovered cells (Figure 1) except at $\mathrm{pH} 11.5$ where most cells were recovered in the insoluble fraction and water contained the fewest. The high numbers of recovered cells in the insoluble fractions is most likely due to centrifugation which would leave fewer cells left within the protein and water fractions (Lansdowne et al., 2009a). According to the U.S. Food and Drug Administration, pasteurization is defined as a 6-log reduction in microbial populations. A net pasteurization effect was not observed at any of the $\mathrm{pH}$ conditions. When microorganisms are placed in an environment below or above neutrality, they need to bring the environmental $\mathrm{pH}$ to a 
more optimum value to survive and proliferate (Burl et al., 1999). Aspects of cell function such as nutrient acquisitions, energy generation, $\mathrm{pH}$ homeostasis and protection of components may be affected by acidic conditions (Rode et al., 2010). In acidic conditions, bacterial cells must either keep protons from entering or expel them as fast as they enter (Jay et al., 2005). On the other hand, high $\mathrm{pH}$ levels may solubilize the bacteria's membrane protein and lipids which can lead to the exposure of hydrophobic sites of adjacent lipids to the environment (Jacobsohn et al., 1992). In Gram-negative bacteria, damage to the membrane protein and lipids by high $\mathrm{pH}$ as well as the exposure of hydrophobic areas of adjacent phospholipids can lead to the disruption of the stability of the membrane and predispose it to rupture by intracellular turgor pressure (Mendonca et al., 1994). However, Gram-positive bacteria such as L. monocytogenes are able to maintain their overall integrity when exposed to high $\mathrm{pH}$ conditions due to the presence of the peptidoglycan cell wall (Shockman and Barrett 1983). The cell wall is able to prevent the swelling and ultimate bursting of the cell by stabilizing the membrane against the turgor pressure exerted by the cytoplasm (Csonka, 1989). Bacteria cells may also use cytoplasmic buffering by synthesizing intracellular metabolites in an attempt to stabilize $\mathrm{pH}$ (Dilworth and Glenn 1999). These mechanisms might explain the generally low number of $\log$ reduction in $S$. aureus populations, but they are only a temporary fix to oppose the increasing $\mathrm{OH}^{-}$concentration.

Strong acids such as $\mathrm{HCl}$ completely dissociate in solutions. The protons tend to pass through the membrane by interacting with the systems that control the proton flow in and out of the cell, such as the electron transport system. On the other hand, weak organic acids exist in a $\mathrm{pH}$-dependent equilibrium between the dissociated and undissociated state in solutions. The dissociation of an acid depends on temperature, $\mathrm{pH}$ and the dissociation constant of the acid (Rode et al., 2010). These acids have optimal antimicrobial activity at low $\mathrm{pH}$ levels because they 
are mostly in their uncharged and undissociated form which easily permeates through the membrane of bacterial cells. Once inside the cell, the molecules will dissociate and release charged anions and protons which will not cross the cellular membrane. The accumulation of these protons and anions will eventually cause membrane disruption (Burl et al., 1999). In the present study, $\mathrm{HCl}$ acid was shown to be more effective $(\mathrm{P}<0.05)$ at reducing $S$. aureus than acetic acid when protein was solubilized under acidic processing conditions (Table 2); however, it is important to point out that microbial reductions were very low, with the average total reduction being less than 1 log. Perhaps increasing the exposure time of $S$. aureus to these acids could result in higher log reductions and would allow us to differentiate between the effectiveness of acids used during ISP.

Otto and others (2011b) determined the effect of organic acids (citric and acetic) on the reduction of $L$. innосиа during ISP processing of rainbow trout. Significant reductions $(\mathrm{P}<0.05)$ were observed in microbial reductions regardless of $\mathrm{pH}$ or acid type. A $6.41 \log \mathrm{CFU} / \mathrm{g}$ reduction was seen in the recovered protein fraction at processing $\mathrm{pH} 3.0$ with acetic acid, compared to a $1.11 \log \mathrm{CFU} / \mathrm{g}$ reduction when $\mathrm{HCl}$ was used as the processing acid (Lansdowne et al., 2009). However, when the same organic acids and processing $\mathrm{pHs}$ were utilized during ISP processing of rainbow trout inoculated with $L$. monocytogenes, only a $3.53 \mathrm{CFU} / \mathrm{g}$ reduction occurred in the protein fraction (Otto et al., 2011a).

In another study, Lansdowne and others (2009) determined the effect of ISP processing at acidic (2.0 and 3.0) and basic (11.5 and 12.5) pH conditions on the survival of L. innocua. They did not observe a net pasteurization effect while using $\mathrm{HCl}$ during ISP processing at any of the processing $\mathrm{pHs}$. The greatest reduction of $L$. innocua in the protein fraction was observed at processing $\mathrm{pH} 2.0$ which resulted in a $3.8 \log$ reduction and the least reduction occurred at $\mathrm{pH}$ 
11.5 (Lansdowne et al., 2009). In contrast, the results of this current study that solubilizing protein at $\mathrm{pH} 2.5$ resulted in a total log reduction of less than one in S. aureus populations; the greatest reduction were observed when protein was solubilized at $\mathrm{pH} 11.5$ and 12.5 .

\section{Conclusion}

The current study indicates that ISP is not an effective process in eliminating Staphylococcus aureus populations. Although, the collected data suggests that weak organic acids are as effective as strong inorganic acids when used during the ISP process at reducing S. aureus; however, the low reductions in microbial populations do not allow us to make a definite conclusion. Basic $\mathrm{pH}$ conditions seem to have a better effect on the reduction of S. aureus during ISP processing. To further investigate the effect of ISP on S. aureus, future research should focus on increasing the exposure time of $S$. aureus to high or low $\mathrm{pH}$ conditions and possibly increasing the initial inoculation levels to better observe the effect of different acids. 


\section{References}

1. Abee, T., and J. A. wouters. 1999. Microbial stress response in minimal processing. Intl. J. Food Microbial. 50:65-91

2. Bore E, Langsrud S, Langsrud O, Rode TM, Holck A. 2007. Acid-shock responses in Staphylococcus aureus investigated by global gene expression analysis. Microbiol. 153:2289-2303.

3. Brashears, M. M., A. Amezquita, and J. Stratton. 2001. Validation of methods used to recover Escherichia coli O517:H7 and Salmonella spp. Subjected to stress conditions. J. Food Prot. 64:1466-1471.

4. Burl S., Coote P.,1999. Preservative agents in foods. Mode of action and microbial resistance mechanisms, Int. J. Food Microbiol., $50: 1-17$

5. Csonka LN. 1989. Physiological and genetic responses of bacteria to osmotic stress. Microbiol Rev 53(1):121-47.

6. Dilworth MJ, Glenn AR. 1999. Problems of adverse pHand bacterial strategies to combat it. Novartis Found Symp 221:4-18

7. Doyle MP, Beuchat LR, Montville TJ. (ed.) 2001. Food Microbiology: fundamentals and frontiers. ASM Press, Washington, D.C.

8. FAO, The State of World Fisheries and Aquaculture 2006. Food and Agriculture Organization of the United Nations, Rome (2007).

9. Gilbert F. Hiram. 2000. Basic concepts in food biochemistry, a student's survival guide. $2^{\text {nd }}$ ed. New York: McGraw-Hill. 331p.

10. Hurst, A. 1997. Bacterial injury: a review. Can. J. Microbiol. 23:935-944.

11. Jacobsohn, M. K., M. M. Lehman, and G. M. Jacobsohn. 1992. Cell membranes and multilamellar vesicles: influence of $\mathrm{pH}$ on solventinduced damage. Lipids 27:694-700.

12. Jay, J., M. Loessner, and D. Golden. 2005. Food protection with chemicals, and by biocontrol, p. 301-350. In D. Heldman (ed.), Modern food microbiology, 7th ed. Springer, New York.

13. Lansdowne, L.R., S. Beamer, J. Jaczynski, and K.E. Matak. 2009a. Survival of Listeria innocua after isoelectric solubilization and precipitation of fish protein. J. Food Sci. 74(4): M201-205. 
14. Lansdowne, L.R., S. Beamer, J. Jaczynski, and K.E. Matak. 2009b. Survival of Listeria innocua after isoelectric solubilization and precipitation of fish protein. J. Food Sci. 74(4): M201-205.

15. Mendonca AF, Amoroso TL, Knabel SJ. 1994. Destruction of Gram-negative foodborne pathogens by high $\mathrm{pH}$ involves disruption of the cytoplasmic membrane. Appl EnvironMicrobiol 60(11):4009-14.

16. Otto, R. A., Beamer, S., Jaczynski, J., Matak, K. E. 2011a. The Effect of Using Citric or Acetic Acid on Survival of Listeria monocytogenes During Fish Protein Recovery by Isoelectric Solubilization and Precipitation Process. J. Food Sci. 76(8):M579-83.

17. Otto, R. A., Paker, I., Bane, L., Beamer, S., Jaczynski, J., Matak, K. E. 2011b. Survival of Listeria inoccua in Rainbow Trout Protein Recovered by Isoelectric Solubilisation and Precipitation with Acetic and Citric Acids. J. Food Prot. 74(8): 1348-1352.

18. Paker, I., Beamer, S., Jaczynski, J. and K.E. Matak. 2013. Compositional Characteristics of Materials Recovered from Headed Gutted Silver Carp (Hypophthalmichthys molitrix) By Isoelectric Solubilization and Precipitation Using Organic Acids. J. Food Sci. 78:E445-451.

19. Rode TM, Møretrø T, Langsrud S, Langsrud O, Vogt G, Holck A. 2010. Responses of Staphylococcus aureus exposed to $\mathrm{HCl}$ and organic acid stress. Can J Microbiol. (56):777(Hypophthalmichthys molitrix) Using Isoelectrical Solubilization/ Precipitation. J. Agric. Food Chem. (57): 4259-4266.

20. Ronaghi, M. 2013. The efficacy of organic acids during isoelectric solubilization and precipitation processing of silver carp on proximate composition and bacterial reduction (Unpublished master's thesis). West Virginia University, Morgantown, WV.

21. Russell, N. J., R. I. Evans, P. F. ter Steeg, J. Hellemons, A. Verheul, and T. Abee. 1995. Membranes as a target for stress adaptation. Int. J. Food Microbiol. 28:255-261.

22. Taskaya, L., Chen, Y.C., Beamer, S., Tou, J. C., Jaczynski, J. 2009. Compositional Characteristics of Materials Recovered from Whole Gutted Silver Carp (Hypophthalmichthys molitrix) Using Isoelectrical Solubilization/ Precipitation. J. Agric. Food Chem. (57): 42594266.

23. US Food and Drug Administration. 2011. Fish and Fisheries Products Hazards and Controls Guidance: Chapter 16. http://www.fda.gov/food/guidancecomplianceregulatoryinformation/guidancedocuments/se 
afood/fishandfisheriesproductshazardsandcontrolsguide/default.htm. Accessed on: March 3, 2013.

24. Wesche, A. M., Gurtler, J. B., Marks, B. P., \& Ryser, E. T. (2009). Stress, sublethal injury, resuscitation, and virulence of bacterial foodborne pathogens. Journal of Food Protection ${ }^{\circledR}, 72(5), 1121-1138$. 
Table 1. Log reduction of S. aureus by ISP processing with acetic and hydrochloric acids in silver carp. Values were determined by subtraction of the log of recovered cells within a fraction from the log of the total initial inoculation (average: 7.10 log CFU/g).

\begin{tabular}{|c|c|c|c|c|c|c|c|c|c|}
\hline \multirow{10}{*}{$\begin{array}{l}\text { Fraction } \\
\text { Protein }\end{array}$} & \multirow[b]{2}{*}{ pH } & \multirow[b]{2}{*}{ Acid } & \multicolumn{2}{|c|}{$\begin{array}{c}\text { Log Reduction } \\
(\text { mean } \log \mathrm{CFU} / \mathrm{g} \pm \mathrm{SD}, n=3)\end{array}$} & \multirow[b]{2}{*}{ Fraction } & \multirow[b]{2}{*}{ pH } & \multirow[b]{2}{*}{ Acid } & \multicolumn{2}{|c|}{$\begin{array}{c}\text { Log Reduction } \\
\text { (mean } \log \text { CFU } / g \pm S D, n=3)\end{array}$} \\
\hline & & & BP & TSA & & & & BP & TSA \\
\hline & 2.5 & Acetic & $0.58 \pm 0.17^{b c}$ & $0.73 \pm 0.23^{c}$ & Lipid & 2.5 & Acetic & $1.05 \pm 0.14^{b}$ & $1.06 \pm 0.21^{\mathrm{b}}$ \\
\hline & & $\mathrm{HCl}$ & $0.97 \pm 0.12^{b c}$ & $1.13 \pm 0.19^{\mathrm{c}}$ & & & $\mathrm{HCl}$ & $1.80 \pm 0.13^{b}$ & $2.00 \pm 0.29^{b}$ \\
\hline & 3.0 & Acetic & $0.31 \pm 0.27^{\mathrm{c}}$ & $0.36 \pm 0.32^{c}$ & & 3.0 & Acetic & $1.09 \pm 0.17^{\mathrm{b}}$ & $1.26 \pm 0.36^{\mathrm{b}}$ \\
\hline & & $\mathrm{HCl}$ & $0.93 \pm 0.29^{b c}$ & $0.90 \pm 0.33^{c}$ & & & $\mathrm{HCl}$ & $1.83 \pm 0.14^{b}$ & $1.79 \pm 0.11^{\mathrm{b}}$ \\
\hline & 11.5 & Acetic & $1.03 \pm 0.39^{b c}$ & $1.23 \pm 0.21^{\mathrm{c}}$ & & 11.5 & Acetic & $1.35 \pm 0.60^{b}$ & $1.60 \pm 0.44^{b}$ \\
\hline & & $\mathrm{HCl}$ & $1.04 \pm 0.14^{b c}$ & $1.42 \pm 0.41^{b c}$ & & & $\mathrm{HCl}$ & $0.77 \pm 0.44^{b}$ & $1.46 \pm 0.85^{b}$ \\
\hline & 12.5 & Acetic & $2.22 \pm 0.54^{\mathrm{a}}$ & $2.77 \pm 0.60^{\mathrm{a}}$ & & 12.5 & Acetic & $4.17 \pm 0.60^{\mathrm{a}}$ & $4.25 \pm 0.78^{a}$ \\
\hline & & $\mathrm{HCl}$ & $1.46 \pm 0.35^{\mathrm{ab}}$ & $2.34 \pm 0.60^{\mathrm{ab}}$ & & & $\mathrm{HCl}$ & $3.64 \pm 0.82^{\mathrm{a}}$ & $3.96 \pm 0.68^{a}$ \\
\hline \multirow[t]{8}{*}{ Insoluble } & 2.5 & Acetic & $0.99 \pm 0.21^{b c}$ & $0.99 \pm 0.09^{b c}$ & \multirow[t]{8}{*}{ Water } & 2.5 & Acetic & $4.10 \pm 0.51^{\mathrm{a}}$ & $4.15 \pm 0.08^{a}$ \\
\hline & & $\mathrm{HCl}$ & $1.64 \pm 0.06^{b}$ & $2.02 \pm 0.37^{\mathrm{b}}$ & & & $\mathrm{HCl}$ & $4.39 \pm 0.36^{\mathrm{a}}$ & $4.05 \pm 0.89^{a}$ \\
\hline & 3.0 & Acetic & $1.13 \pm 0.05^{b c}$ & $1.25 \pm 0.22^{b c}$ & & 3.0 & Acetic & $4.09 \pm 0.97^{\mathrm{a}}$ & $4.16 \pm 1.03^{a}$ \\
\hline & & $\mathrm{HCl}$ & $1.37 \pm 0.20 \mathrm{bc}$ & $1.32 \pm 0.15^{b c}$ & & & $\mathrm{HCl}$ & $4.38 \pm 0.39^{\mathrm{a}}$ & $4.02 \pm 0.35^{\mathrm{a}}$ \\
\hline & 11.5 & Acetic & $0.70 \pm 0.21^{\mathrm{cd}}$ & $1.20 \pm 0.07^{b c}$ & & 11.5 & Acetic & $4.03 \pm 0.61^{\mathrm{a}}$ & $3.93 \pm 0.35^{\mathrm{a}}$ \\
\hline & & $\mathrm{HCl}$ & $0.10 \pm 0.17^{\mathrm{d}}$ & $0.58 \pm 0.34^{\mathrm{c}}$ & & & $\mathrm{HCl}$ & $4.16 \pm 0.20^{\mathrm{a}}$ & $4.52 \pm 0.23^{\mathrm{a}}$ \\
\hline & 12.5 & Acetic & $3.46 \pm 0.62^{a}$ & $4.42 \pm 1.08^{a}$ & & 12.5 & Acetic & $5.15 \pm 0.77^{\mathrm{a}}$ & $5.63 \pm 1.16^{\mathrm{a}}$ \\
\hline & & $\mathrm{HCl}$ & $2.72 \pm 0.35^{a}$ & $4.07 \pm 0.49^{a}$ & & & Acetic & $4.68 \pm 0.16^{\mathrm{a}}$ & $5.27 \pm 0.40^{a}$ \\
\hline \multirow[t]{8}{*}{ Total } & 2.5 & Acetic & $0.26 \pm 0.24^{\mathrm{c}}$ & $0.36 \pm 0.10^{b}$ & & & & & \\
\hline & & $\mathrm{HCl}$ & $0.82 \pm 0.11^{b c}$ & $1.02 \pm 0.20^{b}$ & & & & & \\
\hline & 3.0 & Acetic & $0.20 \pm 0.17^{\mathrm{c}}$ & $0.26 \pm 0.24^{b}$ & & & & & \\
\hline & & $\mathrm{HCl}$ & $0.74 \pm 0.23^{b c}$ & $0.70 \pm 0.27^{b}$ & & & & & \\
\hline & 11.5 & Acetic & $0.33 \pm 0.35^{\mathrm{c}}$ & $0.79 \pm 0.20^{b}$ & & & & & \\
\hline & & $\mathrm{HCl}$ & $0^{\mathrm{c}}$ & $0.28 \pm 0.49^{b}$ & & & & & \\
\hline & 12.5 & Acetic & $2.18 \pm 0.53^{a}$ & $2.73 \pm 0.61^{\mathrm{a}}$ & & & & & \\
\hline & & $\mathrm{HCl}$ & $1.42 \pm 0.35^{\mathrm{ab}}$ & $2.30 \pm 0.56^{\mathrm{a}}$ & & & & & \\
\hline
\end{tabular}


${ }^{\mathrm{a}, \mathrm{b}, \mathrm{c}}$ Values designated with different letters within a column and fraction are significantly different $(P<0.05)$ as determined by Tukey's HSD. Values in bold indicate a significant difference in recovery between BP and TSA $(\mathrm{P}<0.05)$. 
Table 2. Log reduction of S. aureus exposed to several $\mathrm{pH}$ shifts in different fractions of headed and gutted silver carp. Values were determined by subtraction of the log of recovered cells within a fraction from the $\log$ of the total initial inoculation $(7.10 \log \mathrm{CFU} / \mathrm{g})$. Combined data from TSA and BP There were no significant differences in recovery between TSA and BP $(\mathrm{P}>0.05)$.

\begin{tabular}{llll}
\hline Fraction & $\mathbf{p H}$ & Acid & $\begin{array}{l}\text { Log Reduction } \\
\text { (mean log CFU/g } \pm \mathbf{S D}, \mathbf{n}=\mathbf{6})\end{array}$ \\
\hline Protein & $2.5^{*}$ & Acetic & $0.68 \pm 0.20^{\mathrm{cd}}$ \\
& & HCl & $1.05 \pm 0.16^{\mathrm{cd}}$ \\
& $3.0^{*}$ & Acetic & $0.34 \pm 0.26^{\mathrm{d}}$ \\
& HCl & $0.92 \pm 0.28^{\mathrm{cd}}$ \\
& 11.5 & Acetic & $1.13 \pm 0.30^{\mathrm{c}}$ \\
& & HCl & $1.23 \pm 0.34^{\mathrm{bc}}$ \\
& 12.5 & Acetic & $2.49 \pm 0.59^{\mathrm{a}}$ \\
& & HCl & $1.90 \pm 0.66^{\mathrm{b}}$ \\
\hline Lipid & $2.5^{*}$ & Acetic & $1.06 \pm 0.16^{\mathrm{b}}$ \\
& & HCl & $1.90 \pm 0.23^{\mathrm{b}}$ \\
& $3.0^{*}$ & Acetic & $1.17 \pm 0.27^{\mathrm{b}}$ \\
& & HCl & $1.81 \pm 0.15^{\mathrm{b}}$ \\
& 11.5 & Acetic & $1.47 \pm 0.49^{\mathrm{b}}$ \\
& HCl & $1.12 \pm 0.71^{\mathrm{b}}$ \\
& 12.5 & Acetic & $4.21 \pm 0.62^{\mathrm{a}}$ \\
& & HCl & $3.80 \pm 0.70^{\mathrm{a}}$ \\
\hline Total & $2.5^{*}$ & Acetic & $0.31 \pm 0.17^{\mathrm{bc}}$ \\
& HCl & $0.92 \pm 0.18^{\mathrm{b}}$ \\
& $3.0^{*}$ & Acetic & $0.23 \pm 0.19^{\mathrm{bc}}$ \\
& & HCl & $0.72 \pm 0.23^{\mathrm{bc}}$ \\
& 11.5 & Acetic & $0.56 \pm 0.36^{\mathrm{bc}}$ \\
& & HCl & $0.17 \pm 0.38^{\mathrm{c}}$ \\
& 12.5 & Acetic & $2.45 \pm 0.59^{\mathrm{a}}$ \\
& & HCl & $1.86 \pm 0.64^{\mathrm{a}}$ \\
\hline & & &
\end{tabular}

* Indicates significant difference in reductions between acids within treatment $(\mathrm{P}<0.05)$

a, b, c, d Values designated with the different letters within a column and fraction are significantly different $(\mathrm{P}<0.05)$ 

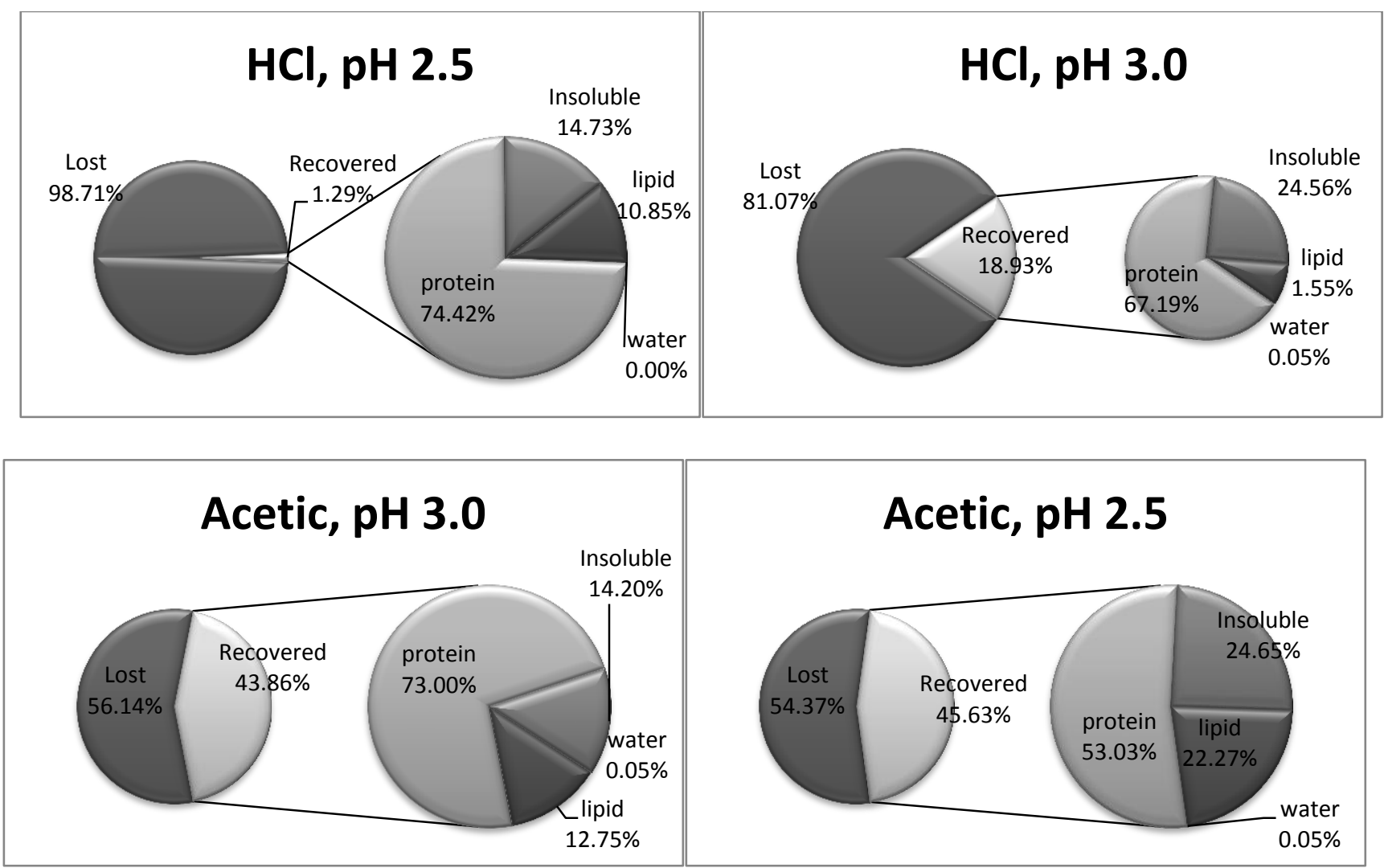

Figure 1. Recovered S.aureus after ISP processing of silver carp at acidic processing $\mathrm{pH}$ levels. The left pie chart indicates the percentage of recovered cells from the initial inoculum and the right pie chart indicates the percentage of recovered cells in each fraction. Total log reduction was calculated by subtracting the summation of survivors in all fraction from the initial inoculum: $\log ($ initial inoculum) $\log$ (survivors in protein fraction + insoluble fraction + lipid fraction + water fraction). The $\log$ reduction in each fraction: $\log ($ initial inoculum) $-\log$ (survivors in specific fraction). 


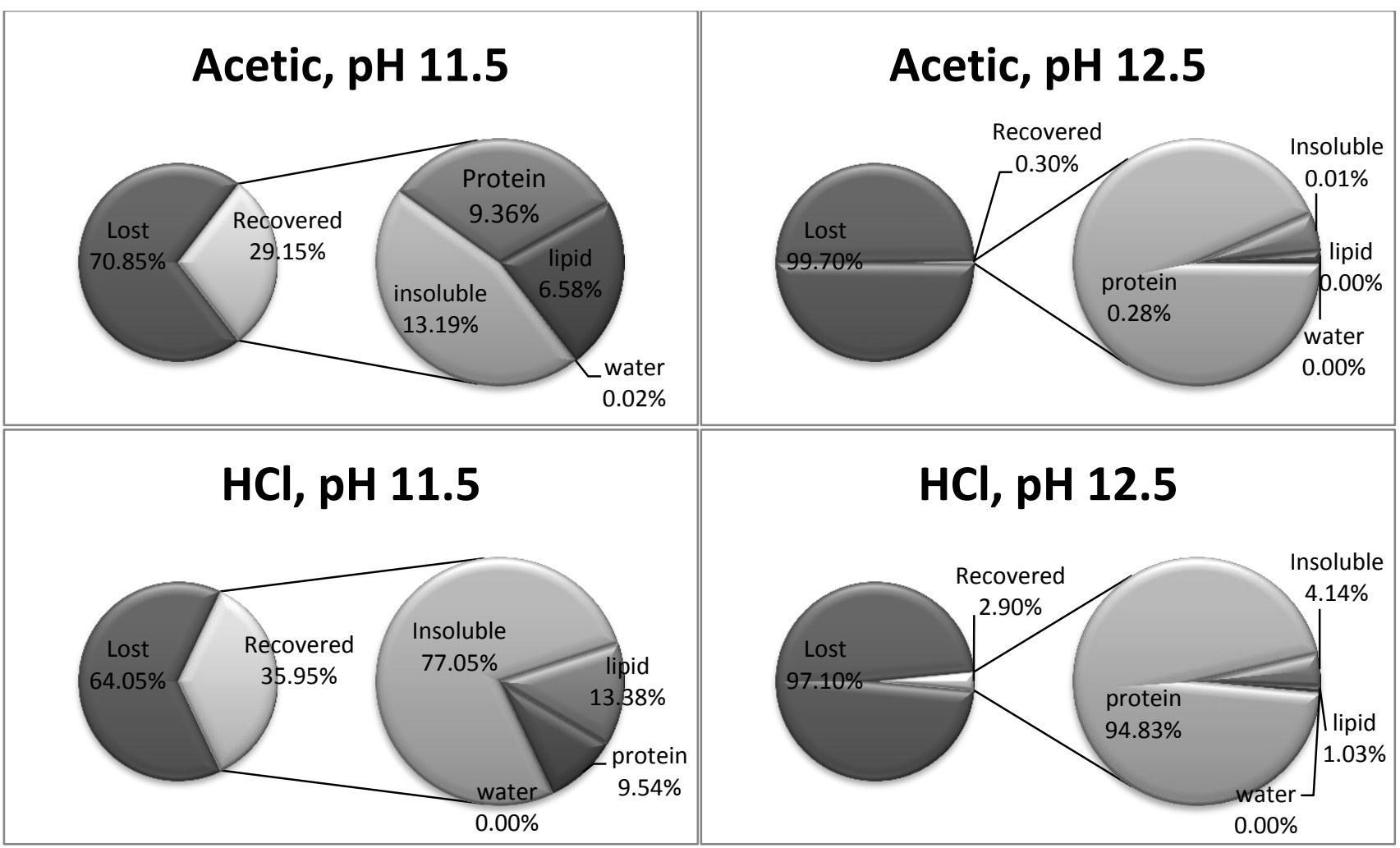

Figure 2. Recovered S.aureus after ISP processing of silver carp at basic processing $\mathrm{pH}$ levels. The left pie chart indicates the percentage of recovered cells from the initial inoculum and the right pie chart indicates the percentage of recovered cells in each fraction. Total log reduction was calculated by subtracting the summation of survivors in all fraction from the initial inoculum: $\log ($ initial inoculum) $-\log$ (survivors in protein fraction + insoluble fraction + lipid fraction + water fraction). The $\log$ reduction in each fraction: $\log ($ initial inoculum $)-\log$ (survivors in specific fraction). 